\title{
The role of the serotonergic system in locomotor recovery after spinal cord injury
}

\author{
Mousumi Ghosh ${ }^{1,2 *}$ and Damien D. Pearse ${ }^{1,2,3,4}$ \\ ${ }^{1}$ The Miami Project to Cure Paralysis, University of Miami Miller School of Medicine, Miami, FL, USA \\ ${ }^{2}$ Department of Neurological Surgery, University of Miami Miller School of Medicine, Miami, FL, USA \\ ${ }^{3}$ The Neuroscience Program, University of Miami Miller School of Medicine, Miami, FL, USA \\ ${ }^{4}$ The Interdisciplinary Stem Cell Institute, University of Miami Miller School of Medicine, Miami, FL, USA
}

\section{Edited by:}

Hans Hultborn, University of

Copenhagen, Denmark

Reviewed by:

Deborah Baro, Georgia State University, USA

Michael A. Lane, University of Florida, USA

Hans Hultborn, University of

Copenhagen, Denmark

*Correspondence:

Mousumi Ghosh, The Miami Project to Cure Paralysis and Department of Neurological Surgery, University of Miami Miller School of Medicine, Lois Pope LIFE Center, P.O. Box 016960, Mail locator R-48, Miami, FL 33101, USA e-mail:mghosh@med.miami.edu
Serotonin (5-HT), a monoamine neurotransmitter synthesized in various populations of brainstem neurons, plays an important role in modulating the activity of spinal networks involved in vertebrate locomotion. Following spinal cord injury (SCl) there is a disruption of descending serotonergic projections to spinal motor areas, which results in a subsequent depletion in $5-\mathrm{HT}$, the dysregulation of $5-\mathrm{HT}$ transporters as well as the elevated expression, super-sensitivity and/or constitutive auto-activation of specific 5$\mathrm{HT}$ receptors. These changes in the serotonergic system can produce varying degrees of locomotor dysfunction through to paralysis. To date, various approaches targeting the different components of the serotonergic system have been employed to restore limb coordination and improve locomotor function in experimental models of SCl. These strategies have included pharmacological modulation of serotonergic receptors, through the administration of specific 5-HT receptor agonists, or by elevating the 5-HT precursor 5-hydroxytryptophan, which produces a global activation of all classes of 5-HT receptors. Stimulation of these receptors leads to the activation of the locomotor central pattern generator (CPG) below the site of injury to facilitate or improve the quality and frequency of movements, particularly when used in concert with the activation of other monoaminergic systems or coupled with electrical stimulation. Another approach has been to employ cell therapeutics to replace the loss of descending serotonergic input to the CPG, either through transplanted fetal brainstem 5-HT neurons at the site of injury that can supply 5-HT to below the level of the lesion or by other cell types to provide a substrate at the injury site for encouraging serotonergic axon regrowth across the lesion to the caudal spinal cord for restoring locomotion.

Keywords: serotonin receptor agonists, serotonin, spinal cord, locomotion control, central pattern generators (CPG)

\section{INTRODUCTION}

Spinal cord injury (SCI) is a devastating condition affecting approximately 273,000 individuals in the US, with 12,000 new cases occurring annually (National Spinal Cord Injury Statistical Center, University of Alabama, https://www.nscisc.uab.edu). Damage to the spinal cord results in the impairment of specific functions controlled by the nerves located at, or below, the level of SCI. According to the presence or absence of motor function, human SCI can be classified as complete or incomplete. Following incomplete injury, a certain degree of movement and sensation below the level of injury may be retained depending upon the severity of the injury and the corresponding extent of axonal preservation. Complete SCI results in paralysis, due to the lack of sensory and motor function below the level of injury, though rarely is SCI anatomically complete in man. One of the major consequences resulting from trauma to the spinal cord is the disruption of the dynamic interactions among the spinal neuronal network, supraspinal pathways and peripheral sensory inputs, which results in an impairment of locomotor function (Kiehn, 2006; Rossignol et al., 2006). This dysfunction is permanent due to the subsequent loss of motor neuron excitability and the inability of the central nervous system (CNS) to mount a robust reparative response endogenously. Although the complete ablation of direct supraspinal projections to regions below the injury results in the cessation of the voluntary control of movements, some residual motor function may remain from the spontaneous reorganization and recovery of neuronal network excitability from plastic changes within any spared ascending and descending systems (Ghosh et al., 2009; Tansey, 2010; Martinez and Rossignol, 2011; Rossignol and Frigon, 2011; D’Amico et al., 2014; El Manira, 2014; Filli et al., 2014).

To repair the injured spinal cord and restore voluntary motor function various strategies have been employed. Among the different approaches used, those that have elicited the sprouting or re-growth of serotonergic fibers caudal to the site of SCI have often been associated with an ensuing improvement in locomotor 
function (Bregman et al., 2002; Engesser-Cesar et al., 2007). The reactivation of the central pattern generator (CPG), an important spinal cord center for locomotor output, and stimulation of the locomotor neural network through (1) the exogenous application of 5-HT (Cazalets et al., 1992; Madriaga et al., 2004; Thompson et al., 2011) or its precursor, L-5-hydroxytryptophan (5-HTP; Hayashi et al., 2010; Meehan et al., 2012); (2) through the administration of agonists for specific serotonergic receptor subsets, either alone (Antri et al., 2002; Landry and Guertin, 2004) or in combination with the stimulation of the dopaminergic (DA) and the noradrenergic (NA) systems (Brustein and Rossignol, 1999; Musienko et al., 2011) or; (3) the transplantation of serotonergic embryonic neurons that can innervate these regions (Privat et al., 1989; Rajaofetra et al., 1989a; Gimenez y Ribotta et al., 1998), have provided convincing evidence in support of an essential and indispensable role for the serotonergic system in promoting the restoration of locomotor function after SCI. Though it has been shown that concurrent stimulation of all the monoaminergic systems, NA, DA and serotonergic (Jordan et al., 2008), is important in the generation of locomotion, the present review will focus specifically on the function of the different components of the serotonergic pathway in regulating motor function output with attention to how these components are altered after SCI and lead to locomotor dysfunction. In addition, the therapeutic modalities that have been employed to modulate the serotonergic system in the CNS, in an attempt to restore locomotor function after experimental SCI, are discussed.

\section{5-HT AND ANATOMICAL LOCALIZATION OF ITS NEURAL PATHWAYS}

5-HT is a monoamine neurotransmitter synthesized from tryptophan, an essential amino acid, by a subset of neurons referred to as serotonergic neurons that are present in the CNS as well as by enterochromaffin cells in the gastrointestinal tract ( $\mathrm{Li}$ et al., 2014). The anatomical localization of 5-HT pathways in the CNS was initially delineated in the rat brain by Dahlstroem and Fuxe (1964), who demonstrated that serotonergic neurons were largely concentrated in the raphe nuclei of the brainstem. Almost all the 5-HT axons found within the mammalian spinal cord originate supraspinally from neurons located in the brainstem (Takeuchi et al., 1982), primarily from three main regions, the medullary raphe pallidus, raphe obscuris and the raphe magnus (Azmitia, 1999), as well as part of the reticular formation that encompasses the pyramidal tract at these levels. The 5-HT axon terminals originating from descending brainstem projections exist at all levels of the spinal cord (Rajaofetra et al., 1989b; Hornung, 2003) and are localized to the dorsal horn, ventral horn and intermediate area (Ballion et al., 2002). Serotonergic projections innervating the dorsal horn predominantly arise from the raphe magnus via the dorsolateral funiculus, which also has sparse projections in the ventral horn. The neurons in the raphe obscuris and pallidus project to the ventrolateral white matter as well as terminate onto motoneurons in the ventral horn and in the intermediate gray via the ventral and ventrolateral funiculi, respectively (Azmitia and Gannon, 1986). The axon collaterals from a single raphe neuron are able to innervate both the sensory and motor nuclei of the autonomic system at different spinal levels, including both cervical and lumbar regions of the spinal cord (Martin et al., 1981).

Previously, Rajaofetra et al. (1992a) demonstrated in adult baboons that serotonergic innervation of the Onuf's nucleus, located in the ventrolateral part of the sacral spinal cord, was of both supraspinal and intraspinal origin. Supraspinal innervation was found to exist throughout the whole nucleus, with a predominance in the dorsal half, while the intraspinal innervation was primarily associated with the ventral half of the nucleus. Subsequently, Branchereau et al. (2002) reported in organotypic spinal cord cultures, which lacked descending serotonergic input, the expression of 5-HT in intraspinal neurons; these 5-HT intraspinal neurons were able to compensate for the lack of the descending supraspinal 5-HT fibers and contribute to the development of spontaneous locomotor activity. The 5-HT expressed by these intraspinal neurons was dependent upon the absence of 5-HT fibers as 5 -HT from the descending input repressed expression of 5-HT from these intraspinal neurons. In the human spinal cord, Perrin et al. (2011) have mapped 5-HT profiles in the thoracic and lumbar segments, finding a similar neuroanatomical localization to that of rodents and non-human primates where serotonergic processes were identified primarily within the ventral horn surrounding motoneurons as well as also in the intermediolateral region and in the superficial part of the dorsal horn.

\section{FUNCTION OF THE SEROTONERGIC PATHWAY IN LOCOMOTION}

Multiple descending tracts from the brainstem function in the initiation and regulation of locomotion, including the glutamatergic, NA, DA and 5-HT pathways. These functions are mediated through the action of various neurotransmitters such as glutamate, NA, 5-HT and DA, which induce spinal motor activity, stimulate rhythmic activity and control segmental reflexes (Humphreys and Whelan, 2012; Beliez et al., 2014; Sławińska et al., 2014a). The role of 5-HT in locomotion remains, however, only partially understood. Experimental work from a number of research laboratories have provided convincing evidence that 5 -HT regulates the rhythm and coordination of movements through the CPG. The CPG constitutes a major anatomical component of locomotion comprised of neurons distributed within a neural network in the thoraco-lumbar spinal cord that drives motoneuron output to generate simple rhythmic patterns, such as locomotion (Grillner and Walleń, 1985; Kiehn and Kullander, 2004). 5-HT has been recognized as a potent neuromodulator of CPG activity (Feraboli-Lohnherr et al., 1997). The CPG in the lumbar spinal cord is regulated both by supraspinal descending inputs that originate in the raphe nucleus and terminate in the intermediate gray and the ventral horn (Carlsson et al., 1963; Ballion et al., 2002) as well as by sensory afferents (Rossignol et al., 1988).

The neuronal network of the CPG, in response to monoaminergic input from the brainstem, contributes to the regulation of postural muscle tone and locomotion by determining which components of the specific locomotor program are necessary at a required or specific moment with respect to velocity, magnitude 
and duration (Takakusaki et al., 2004). Under normal conditions, the different motor programs existing in the brainstem remain in a state of inhibition during rest (Grillner, 2006; Hikosaka, 2007). Fornal et al. initially suggested that under these conditions serotonergic neurons are controlled by tonic feedback inhibition (Fornal et al., 1994). When locomotion is initiated, signals activating the locomotor network in the mesencephalic locomotor region (MLR) and the diencephalic locomotor region (DLR) of the midbrain converge on reticulospinal neurons in the brainstem, which determine the extent and duration of locomotor activity that is necessary to be generated by the CPG. Therefore, the MLR, when subjected to electrical or chemical stimulation, triggers bouts of locomotion and elicits movement by activating the reticulospinal pathways (Shik et al., 1966; Garcia-Rill et al., 1985; Sholomenko and Steeves, 1987; Steeves et al., 1987). The initial synaptic targets of the MLR are neurons in the medial pontomedullary reticular formation (MdRF), after which their axons descend as the reticulospinal tract within the ventrolateral funiculus of the spinal cord to synapse on CPG neurons within the cervical or lumbar segments (Steeves and Jordan, 1984; GarciaRill et al., 1985; Noga et al., 1991).

As first discussed by Jacobs and Fornal (1993), the primary function of 5-HT neurons in the brainstem is to facilitate motor output during periods of tonic motor activity, such as postural shifts, or to control repetitive motor behaviors that are mediated by the spinal cord CPGs, such as locomotor speed. However, when the spinal cord is injured, there can be significant disruption or complete severing of the serotonergic projections, as well as other descending systems, to the CPG and loss of locomotor output. When exogenous 5-HT or selective 5-HT receptor agonists are supplied systemically or intraspinally after SCI, in combination with sufficient excitation by epidural electrical stimulation (EES) or glutamate, these locomotor behaviors can be re-elicited (Schmidt and Jordan, 2000; Antri et al., 2002; Landry et al., 2006; Courtine et al., 2009; Fouad et al., 2010).

5-HT participates directly in modulating motor function output through its binding to specific 5-HT receptors present upon the membrane of motoneurons. Depending on the specific receptor subtypes that are activated, either depolarization or hyperpolarization of the motoneurons occurs-thus 5-HT acts a control point in the regulation of spinal motoneuron excitability, leading to an amplification of synaptic excitation or inhibition (Perrier et al., 2013). Early studies employing selective 5-HT receptor agonists and antagonists provided evidence that the activation of $5-\mathrm{HT}_{1 \mathrm{~A}}$ receptors could mediate inhibitory responses, whereas excitation was produced by the activation of $5-\mathrm{HT}_{2 \mathrm{~A}}$ receptors (Bayliss et al., 1995). Excitatory neurotransmission by 5 -HT occurs through the modulation of various ion channels which leads to a sustained depolarization due to the presence of persistent inward currents that are mediated by voltage sensitive $\mathrm{Ca}^{2+}$ and $\mathrm{Na}^{+}$conductance to cause an amplification of synaptic input. Following SCI, there is a reduced input of brain stem-derived 5-HT which results in an altered membrane potential of the motoneurons causing an acute suppression of motoneuron excitability. This is attributed to various factors such as motoneuron hyperpolarization coupled to an acute disappearance of voltage-activated sodium and calcium persistent inward currents which prevents activation of action potentials. This inhibits motoneuron firing and increases presynaptic inhibition thereby rendering the motoneuron and spinal neuronal circuitry unexcitable acutely after the injury. 5-HT can also modulate motoneuron excitability indirectly through its effects on spinal interneurons where 5-HT can alter the action potential properties of these interneurons, especially following SCI. It has been observed in mouse lumbar V2a spinal interneurons (Husch et al., 2012) that an enhanced 5-HT super sensitivity occurs after SCI due to the elevated density of $5-\mathrm{HT}_{2} \mathrm{C}$ receptors on the cell membrane without promoting any significant changes in their level of excitability. 5-HT thus participates in regulating the firing frequency and excitability of spinal motor neurons, which corresponds to its ability to control the speed and amplitude of locomotion as well as alter the membrane properties of spinal interneurons (Harris-Warrick and Cohen, 1985; Zhang and Grillner, 2000; D’Amico et al., 2014; Wienecke et al., 2014) to promote increased motoneuron excitability. SCI-induced losses of 5-HT, however, can lead not only to an absence of motoneuron excitability and locomotor output but residual 5-HT or activity of its receptors may also produce aberrant motoneuron excitability that is involved in triggering spasticity and/or impaired motor output that can hinder normal locomotion (Perrier et al., 2013). This is an outcome observed following chronic SCI, where persistent inward currents are enhanced either due to compensatory over-expression of spontaneously active $5-\mathrm{HT}_{2}$ receptors (Murray et al., 2010) or as a result from a depolarized chloride reversal potential (Boulenguez et al., 2010).

\section{5-HT RECEPTOR ACTIVATION AND LOCOMOTION}

The different members of the 5-HT family of receptors are located within distinct areas of the central and the peripheral nervous systems, as well as in non-neuronal tissues, and are involved in a diversity of functions. The 5-HT receptor family represents one of the most complex families of neurotransmitter receptors that have been characterized to date. Studies conducted by a number of research groups have provided convincing experimental evidence that the descending serotonergic system modulates spinal reflexes and motor function/hind limb coordination through the activation of specific 5-HT receptors, which in turn cause an increase in motoneuron and interneuron excitability and the generation of CPG-mediated locomotor output (Schmidt and Jordan, 2000; Hochman et al., 2001; Pflieger et al., 2002).

A number of 5-HT receptor subtypes are expressed in high density on the membranes of motoneurons, including $5-\mathrm{HT}_{1 \mathrm{~A}}$, $5-\mathrm{HT}_{1 \mathrm{~B}}, 5-\mathrm{HT}_{1 \mathrm{D}}, 5-\mathrm{HT}_{2 \mathrm{~A}}, 5-\mathrm{HT}_{2 \mathrm{~B}}, 5-\mathrm{HT}_{2 \mathrm{C}}$ and $5-\mathrm{HT}_{5 \mathrm{~A}}$ (Perrier et al., 2013) as well as some spliced variants, 5- $\mathrm{HT}_{3}, 5-\mathrm{HT}_{4}, 5-$ $\mathrm{HT}_{6}, 5-\mathrm{HT}_{7}$ and RNA edited isoforms, such as $5-\mathrm{HT}_{2 \mathrm{C}}$ (Werry et al., 2008). These receptors mostly exist as homodimers, although they may also undergo heterodimerization (Renner et al., 2012). Dimerization occurs during their biosynthesis within the endoplasmic reticulum, which is important for their subsequent transport and expression in the plasma membrane as well as maximizes downstream coupling with the G-protein subunits (Herrick-Davis, 2013) that leads to motoneuron excitability. Delineating the signaling mechanisms regulated by 5 -HT has been 
difficult due to both the existence of multiple 5-HT receptor isoforms that are activated in the presence of 5-HT as well as the unavailability of highly selective pharmacological modulators that can act on single receptor subtypes. In the human brain, 13 5-HT GPCRs and one serotonin-gated ion channel receptor, 5- $\mathrm{HT}_{3}$, have been identified (Millan et al., 2008; Lambe et al., 2011). Though 5-HT receptors have been classified under seven known subfamilies, 5- $\mathrm{HT}_{1}$ through $5-\mathrm{HT}_{7}$, post-genomic modifications, such as alternative mRNA splicing or mRNA editing, have resulted in the identification of at least 30 distinct 5-HT receptor subtypes (Raymond et al., 2001). It has been demonstrated that the combined activation of more than one 5 -HT receptor subtype is required for the generation of locomotor output, with signaling originating primarily from $5-\mathrm{HT}_{1 \mathrm{~A}}$, $5-\mathrm{HT}_{2 \mathrm{~A} / \mathrm{C}}$ and $5-\mathrm{HT}_{7}$ receptor subtypes (Jordan et al., 2008). Work to date in characterizing 5-HT receptor activation involvement in real or fictive locomotor output have focused largely on motoneurons, as they are the direct effecters of locomotor activity, in addition to the spinal interneurons that comprise the CPG.

With the availability of agonists and antagonists that exhibit greater selectivity for specific 5-HT receptor subtypes, studies have begun to identify which 5 -HT receptor subtypes mediate specific locomotor behaviors. Employing receptor-specific agonists and antagonists, which have varying binding affinities towards each of the 5-HT receptor subsets, researchers have identified 5- $\mathrm{HT}_{1 \mathrm{~A}}, 5-\mathrm{HT}_{2 \mathrm{~A} / 2 \mathrm{C}}$ (Courtine et al., 2009), 5- $\mathrm{HT}_{3}$ (Guertin and Steuer, 2005), and 5- $\mathrm{HT}_{7}$ receptors (Liu et al., 2009) as important players in the regulation of the spinal locomotor network and which are able to generate locomotion in experimental models of SCI when employed in conjunction with the activation of other monoaminergic systems (Kim et al., 2001a; Antri et al., 2003; Fuller et al., 2005; Madriaga et al., 2004; Guertin and Steuer, 2005; Ung et al., 2008; Courtine et al., 2009; Liu et al., 2009; Musienko et al., 2011). Studies employing 5-HT receptor selective agonists and antagonists in rats following spinal transection have identified that $5-\mathrm{HT}_{2}$ receptors are predominantly responsible for mediating the depolarizing effects resulting from decreased potassium conductance in response to a 5-HT stimulus (Jacobs and Fornal, 1993; Harvey et al., 2006; Li et al., 2007; Perrier et al., 2013; Gackière and Vinay, 2014). In experiments carried out by Ung et al. (2008), in which behavioral and kinematic analyses were performed at 1 week after complete spinal cord transection in mice, they identified the involvement of specific $5-\mathrm{HT}_{2}$ receptor subtypes in locomotor-like movements through the use of selective antagonists. The non-selective $5-\mathrm{HT}_{2}$ receptor agonist quipazine was able to induce locomotor-like movements in the presence of the selective $5-\mathrm{HT}_{2}$ antagonists SB204741 and SB242084, which are inhibitory towards $5-\mathrm{HT}_{2 \mathrm{~B}}$ or $5-\mathrm{HT}_{2 \mathrm{C}}$, respectively. In contrast, quipazine failed to induce locomotor-like movements in animals that had been pretreated with MDL-100,907, a selective 5- $\mathrm{HT}_{2 \mathrm{~A}}$ antagonist. This work provided evidence that $5-\mathrm{HT}_{2 \mathrm{~A}}$ receptors were involved in spinal locomotor network activation and the generation of locomotorlike movements induced by quipazine in transected animals. Antri et al. (2003) showed that the combined, daily stimulation of $5-\mathrm{HT}_{2}$ and $5-\mathrm{HT}_{1 \mathrm{~A}}$ receptors, using quipazine and 8-OHDPAT, respectively, after thoracic spinal cord transection in rats was more potent in restoring locomotion then when the $5-\mathrm{HT}_{2}$ agonist was employed alone, suggesting a cumulative effect of activating the two receptor subtypes in facilitating locomotion. $5-\mathrm{HT}_{1 \mathrm{~A}}$ receptors are localized throughout the CNS with high expression in limbic regions and in the dorsal raphe nucleus, while in the spinal cord, $5-\mathrm{HT}_{1 \mathrm{~A}}$ receptors are identified primarily within the ventral horn surrounding motoneurons, although 5$\mathrm{HT}_{1 \mathrm{~A}}$ receptors are more densely expressed at the lumbar level of the spinal cord. $5 \mathrm{HT}_{1 \mathrm{~A}}$ receptors have been shown to produce hyperpolarization preferentially in a small subset of neurons, such as CA1 hippocampal neurons (Bobker and Williams, 1990; Levkovitz and Segal, 1997) and interneurons (Segal, 1990a,b). Therefore depending upon the specific receptor that 5-HT binds to, it can elicit either depolarizing or hyperpolarizing effects.

\section{CAUDAL SEROTONERGIC AXON INNERVATION AND 5-HT LEVELS AFTER SCI AND THEIR EFFECTS ON RECOVERY}

With 5-HT release within the spinal cord ventral horn playing a major role in mediating locomotor function, it is not surprising that following SCI, when there is severing of supraspinal serotonergic projections and depletion of 5-HT (Carlsson et al., 1963), that loss of 5-HT is one of the major limiting factors that prevents the recovery of motor function (Hashimoto and Fukuda, 1991). 5-HT loss after SCI is characterized by significant reductions or an absence of important enzymes such as tryptophan hydroxylase (TPH), which catalyzes the conversion of tryptophan to 5hydroxytryptophan (5-HTP), that are necessary to generate 5-HT (Clineschmidt et al., 1971). Loss of 5-HT prevents the activation of the spinal locomotor CPG, interfering with the ability to evoke normal locomotion. When 5-HT levels are restored, locomotor function after SCI has been shown to be improved (Pearlstein et al., 2005).

Previous work by Hentall et al. (2006) characterized the spatial and temporal patterns of 5-HT release in the rodent lumbar spinal cord following electrical stimulation of the raphe magnus in SCI rats subjected to acute spinal cord transection at T6-T7. Their findings indicated that the action of monoamines in the spinal cord involves a combination of both synaptic neurotransmission as well as non-synaptic diffusion, similar to that previously observed (Bach-y-Rita, 1999). Noga et al. (2004) employed fast cyclic voltammetry, capable of measuring monoamines such as 5-HT at high spatial resolution in comparison to microdialysisHPLC, to map the basal and steady-state extracellular distribution of monoamines released from tonically active, descending nerve terminals in the lumbar spinal cord of rats when at rest and after spinal cord transection. Their results demonstrated that at rest there was a greater concentration of 5-HT localized in specific regions of the dorsal and ventral horn of the lumbar cord as well as in the lateral region of the intermediate zone which varied within the different segments of the lumbar cord. Following thoracic spinal cord transection, a transient injury evoked increase in monoamine levels was noted briefly acutely within the distal stump of the transected cord. Maximal levels were measured in the superficial dorsal horn of the lumbar cord during this transient period after which there was a steady longer lasting decrease in monoamine levels (Noga et al., 2004). 
Recently, Gerin et al. (2010) examined temporal alterations in the level of endogenous 5-HT release in the ventral horn of rats that were subjected to a sub-hemi-section of the spinal cord at the T9 vertebral level. Release of 5-HT was measured using a microdialysis probe and HPLC analysis, with results showing variations in the levels after SCI over a period of a month during the post-injury recovery period as well when the injured animals were subjected to treadmill exercise. It was found that a significant decrease in 5-HT levels occurred after SCI, which was $<50 \%$ of that observed in non-lesioned animals, indicative of serotonergic denervation. With time post-SCI, 5-HT levels were found to rise, increasing by $202 \%$ at 18 days post injury compared to the levels observed at 8 days post-lesion, which correlated with the timing of motor function recovery. When treadmill exercise was performed, a $\sim 10 \%$ decrease in 5-HT levels was observed compared to rest at 18 and 34 days post-SCI.

\section{ALTERATIONS IN 5-HT RECEPTOR ACTIVITY AFTER SCI}

Previous studies using a complete spinal transection in the cat have shown that SCI leads to an immediate and dramatic reduction in motoneuron excitability (Hounsgaard et al., 1988; Miller et al., 1996). Spinal cord contusion in rodents, an incomplete SCI paradigm that is more clinically-relevant, leads to the preservation of a small number of serotonergic fibers that can undergo sprouting with time following an injury. The degree of locomotor function restoration observed after SCI has been reported to correlate to the density of sprouting of residual, uninjured serotonergic axons (Holmes et al., 2005; Nardone et al., 2014). The use of 5-HT receptor agonists in animals after an acute spinal transection has been shown to produce restoration of motoneuron excitability (Harvey et al., 2006; Li et al., 2007; Musienko et al., 2011; Sławińska et al., 2014a). Work by various researchers have demonstrated that locomotor-activated spinal neurons, which constitute the CPG network, are innervated by serotonergic fibers (Johnson et al., 2002; Perrin et al., 2011; Sławińska et al., 2014b) and that 5 -HT is released within these sites during locomotor activity (Gerin et al., 2008). Together, these results have shown that serotonergic innervation and the availability of 5-HT in the lumbar cord (Antri et al., 2002) are critical for the restoration of hind limb motor function following SCI.

The loss of 5-HT can be overcome through the direct activation of 5-HT receptors, an approach which has been convincingly associated with the induction of locomotor output following SCI (Brustein and Rossignol, 1999; Feraboli-Lohnherr et al., 1999; Kim et al., 2001b). With the reduction or loss of 5-HT input caudal to the injury in rodent models of SCI, it has been demonstrated that there is a compensatory over-expression of 5-HT receptors (Fuller et al., 2005; Navarrett et al., 2012; Ren et al., 2013). In the lamprey, a vertebrate that exhibits locomotor recovery after complete SCI, a transient over-expression of the $5-\mathrm{HT}_{1 \mathrm{~A}}$ receptor transcript is observed for several weeks after SCI (Cornide-Petronio et al., 2014). In rats, Kong et al. (2010) reported a dramatic increase in $5-\mathrm{HT}_{2 \mathrm{~A}}$ receptor immunoreactivity in motoneurons caudal to the site of spinal cord transection, beginning 1 day after injury and persisting to maximal expression by 28 days which paralleled a concurrent reduction in the levels of 5-HT and the 5-HT transporter (Kong et al., 2011; Husch et al.,
2012). Work by Otoshi et al. (2009) examined the influence of descending serotonergic input and sensory feedback on spinal 5 -HT receptor expression using two paradigms. The first was a complete thoracic (T7-T8) spinal cord transection in adult rats, to eliminate supraspinal 5-HT input, while the second employed animals subjected to spinal cord isolation, so as to completely ablate both descending supraspinal as well as peripheral sensory input, completely eliminating any neuromuscular activity. They found that there was an enhanced expression of the $5-\mathrm{HT}_{1 \mathrm{~A}}$ receptor after transection that was dependent upon the presence of sensory input.

Murray et al. (2010) have provided findings that may explain how motoneurons are able to mediate some residual hind limb function in rodent models of complete spinal cord transection (S2, sacral spinal level) or with staggered hemisection, both of which remove the descending supraspinal projections caudal to the level of SCI. It appears that this residual function can arise as a result of alterations in 5-HT receptor expression and their constitutive activation as a compensatory mechanism. A SCI-induced alteration in the levels of the $5-\mathrm{HT}_{2} \mathrm{C}$ receptor has been correlated to a change the post-transcriptional editing of its mRNA that results in both elevated production and constitutive activation. SCI-mediated constitutive activation of $5-\mathrm{HT}_{2} \mathrm{C}$ receptors is able to restore large persistent calcium currents in motoneurons, which in turn is able to induce sustained muscle contractions and the restoration of motor function. Therefore, despite the non-availability of a serotonergic stimulus following SCI, which results in loss of motoneuron excitability acutely, a compensatory upregulation of spontaneously active $5-\mathrm{HT}_{2}$ receptors induced at chronic stages after SCI appears to be an adaptive mechanism which could be responsible for residual locomotor function.

The use of EES, applied onto the dorsal surface of the lumbar spinal cord or given intraspinally, has been used in decerebrated and acute spinal cord transected cats (Iwahara et al., 1992; Gerasimenko et al., 2007) as well as in rats (Ichiyama et al., 2005) to activate the spinal locomotor circuits so as to induce hind limb movements and locomotion (Gerasimenko et al., 2007; Courtine et al., 2009). The use of EES in SCI patients, to promote locomotor function, was first employed by Dimitrijevic et al. (1998), later optimized in paralyzed individuals in work by Shapkova et al. (Shapkova and Schomburg, 2001; Shapkova and Mushkin, 2002; Shapkova, 2004) and is currently being evaluated in clinics in the US (Harkema et al., 2011). Recently, Angeli et al. (2014) successfully used epidural stimulation to activate spinal circuitry in completely paralyzed American Spinal Injury Association Impairment Scale (AIS) A patients, opening a new avenue for therapeutic interventions to promote functional recovery after SCI. Through the use of immunohistochemistry, Noga et al. (2009) showed the co-localization of serotonergic axons with specific 5-HT receptor subtypes $5-\mathrm{HT}_{1 \mathrm{~A}}, 5-\mathrm{HT}_{2 \mathrm{~A}}$ and $5-\mathrm{HT}_{7}$, on c-Fos immunoreactive neurons within laminae VII and VIII of the thoraco-lumbar spinal cord segments following EES in pancuronium-paralyzed, decerebrate cats. The presence of these 5-HT receptor subtypes on these spinal neurons in T13-L7 spinal cord indicates that they likely play a role in 5-HT's modulation of locomotion.

To assess the roles of the specific 5-HT receptor subtypes after SCI that have been identified to be involved in locomotor 
output function; 5- $\mathrm{HT}_{1 \mathrm{~A}}$ (Courtine et al., 2009), 5- $\mathrm{HT}_{2 \mathrm{~A} / 2 \mathrm{C}}$ (Courtine et al., 2009), 5- $\mathrm{HT}_{3}$ (Guertin and Steuer, 2005) and 5- $\mathrm{HT}_{7}$ (Liu et al., 2009), Musienko et al. (2011) conducted experiments using pharmacological manipulations with combinations of receptor specific agonists and/or antagonists. These studies were performed in adult rats subjected to a complete spinal cord transection at the mid-thoracic vertebral level (T7) and the effects of receptor manipulations on observed functional recordings were analyzed during locomotion enabled by EES. From these studies, specific functional roles for each of the 5-HT receptors in modulating motor function output were identified. It was shown that when transected animals were pretreated with the $5-\mathrm{HT}_{7}$ specific antagonist SB269970, prior to the administration of 8-OHDPAT, a dual agonist for $5-\mathrm{HT}_{1 \mathrm{~A} / 7}$, and used in conjunction with EES, a marked improvement in the animal's stepping patterns and inter-limb coordination was observed along with a reduction in kinematic variability and an increase in weight-bearing capacity. These improvements were not seen when EES was used alone, demonstrating an essential role of $5-\mathrm{HT}_{1 \mathrm{~A}}$ receptors in facilitating locomotion, as also reported by other groups (Antri et al., 2003; Courtine et al., 2009). Similarly, they observed that activation of $5-\mathrm{HT}_{2 \mathrm{~A} / \mathrm{C}}$ receptors with the general $5-\mathrm{HT}_{2}$ receptor agonist quipazine, in the presence of EES, produced facilitation of extension of the distal joints along with an improvement in weight-bearing capacity that was not observed with EES alone. When the $5-\mathrm{HT}_{3}$ receptor agonist SR57227A was used with EES, the animals exhibited both an enhancement in weight-bearing as well as a reduction in gait timing variability and paw dragging. The combined activation of $5-\mathrm{HT}_{7}$ and $5-\mathrm{HT}_{1 \mathrm{~A}}$ receptors with $\mathrm{EES}$ also elicited an improvement in stepping pattern and produced a potent facilitation in joint flexion, while combined activation of 5$\mathrm{HT}_{7}$ and 5- $\mathrm{HT}_{2 \mathrm{~A} / \mathrm{C}}$ receptors improved inter-limb coordination, reduced the duration of dragging and substantially increased weight bearing capacity. Finally, the simultaneous activation of all four receptor subtypes, $5-\mathrm{HT}_{1 \mathrm{~A}}, 5-\mathrm{HT}_{2 \mathrm{~A} / \mathrm{C}}$ and $5-\mathrm{HT}_{7}$, with EES led to a significant increase in the EMG activity of the proximal extensor and flexor muscles compared with the stepping pattern elicited by EES alone. These results suggest that it may be necessary to target multiple 5-HT receptors in combination to obtain maximal efficacy in overall locomotor output in the presence of EES (Musienko et al., 2011), although it remains to be tested whether altering the sequential stimulation of different receptor subtypes will be needed to obtain optimal locomotor output.

In addition to pharmacological modification of specific 5-HT receptor subtypes, more recent work has focused on the use of molecular tools to examine receptor function using knockout approaches in transgenic animals. In mice lacking the $5-\mathrm{HT}_{1 \mathrm{~A}}$ receptor, work by Scullion et al. (2013) confirmed the important role of $5-\mathrm{HT}_{1 \mathrm{~A}}$ receptors in the generation of locomotion. $5-\mathrm{HT}_{1 A}$ knockout mice showed higher movement thresholds and smaller motor maps compared with wild-type animals. Increased use of transgenic animals, particularly conditional knockouts, to study the role of specific receptor subtypes in the spinal cord should be undertaken to provide a more specific approach than pharmacological agents for dissecting the function different 5-HT receptors play in the generation of motor output, both under normal locomotion and in the context of locomotor recovery following SCI.

\section{DIFFERENTIAL ACTIVITY OF 5-HT RECEPTOR SUBTYPES IN INDUCING LOCOMOTION AFTER SCI}

Although 5-HT acts on its multiple receptor subtypes, it can trigger different signaling pathways that may have excitatory (Cazalets et al., 1992; MacLean et al., 1998) or inhibitory (Schmidt and Jordan, 2000) effects on motor output. Depending on which 5HT receptors are expressed and activated as well as their cellular and/or specific regional localization within the injured spinal cord, the serotonergic system can produce differential effects on locomotion (Landry et al., 2006; Courtine et al., 2009). Such a variation in response has been noted in phrenic motoneurons where 5-HT displays a differential effect elicited by the $5-\mathrm{HT}_{1 \mathrm{~B}}$ and $5-\mathrm{HT}_{2 \mathrm{~A}}$ receptor subtypes, where by one acts in a stimulatory capacity and the other is inhibitory (Holtmanj et al., 1986; Lalley, 1986). Work by Di Pasquale et al. (1997) showed that while $5-\mathrm{HT}_{2 \mathrm{~A}}$ activation mediated neuronal depolarization of phrenic motoneurons, pharmacological activation of the $5-\mathrm{HT}_{1 \mathrm{~B}}$ receptor resulted in the opposite effect, with inhibition of phrenic activity. This inhibition could be prevented by pre-treatment with $5-\mathrm{HT}_{1 \mathrm{~B}}$ receptor specific antagonists, indicating that opposite effects could be evoked in response to the activation of these two receptor subtypes. Thus $5-\mathrm{HT}$ is able to regulate phrenic motoneuron firing via activation of spinal postsynaptic $5-\mathrm{HT}_{2 \mathrm{~A}}$ and presynaptic $5-\mathrm{HT}_{1 \mathrm{~B}}$ receptors, which in turn function to protect the diaphragm from overstimulation during a non-respiratory action such as vomiting or defecation. Similar differential effects of 5-HT elicited by different 5 -HT receptor subtypes have also been demonstrated in spinalized rats, where monosynaptic transmission is inhibited or stimulated with the activation of $5-\mathrm{HT}_{1 \mathrm{~A}}$ and $5-\mathrm{HT}_{2 \mathrm{~A} / 2 \mathrm{C}}$ receptors, respectively (Hasegawa and Ono, 1996). Using specific agonists for $5-\mathrm{HT}_{1}$ and $5-\mathrm{HT}_{2}$ receptor subtypes, differential effects on hind limb locomotor activity in adult mice after complete thoracic spinal cord transection were reported (Landry and Guertin, 2004). While $5-\mathrm{HT}_{2 \mathrm{~A} / 2 \mathrm{C}}$ receptor agonists facilitated locomotion, stimulating $5-\mathrm{HT}_{2 \mathrm{~B} / 2 \mathrm{C}}$ or $5-\mathrm{HT}_{1 \mathrm{~B}}$ receptors not only failed to induce locomotor-like movements, but also abated the hind limb movements induced by the non-specific 5-HT receptor agonist quipazine, when combined with L-DOPA. The involvement of $5-\mathrm{HT}_{2}$ receptors in mediating excitation has also been shown in the completely transected cat spinal cord where restoration of extensor reflex excitability could be achieved only with 5$\mathrm{HT}_{2 \mathrm{~A} / 2 \mathrm{C}}$ specific agonists in contrast to $5-\mathrm{HT}_{1 \mathrm{~A}}$ and $5-\mathrm{HT}_{1 \mathrm{~B} / \mathrm{D}}$ receptors, which were determined to be ineffective (Miller et al., 1996).

\section{SERTs AND LOCOMOTION AFTER SCI}

Neurotransmission between two or more cell types occurs primarily through volume or synaptic transmission where, with the former, the point of release of the neurotransmitter might be at a distant location from that of the target cells. Volume transmission is associated with nonsynaptic interneuronal 
communication involving a widespread activation of extrasynaptic as well as intrasynaptic receptors (Agnati et al., 1986). This produces a longer duration in the transmission of the signal and requires the diffusion of the neurotransmitter. In comparison, synaptic transmission occurs within a relatively constrained region of the synaptic cleft, between the pre- and the post-synaptic neurons. The duration of 5-HT signaling is regulated by the function of two types of transporters. The vesicular monoamine transporter (VMAT) which pumps 5-HT from the cytoplasm into synaptic vesicles and thereby controls the release of 5-HT from the presynaptic neurons. The other is the serotonin re-uptake transporter (SERT) which exists in the presynaptic plasma membrane of the serotonergic neurons and re-absorbs extracellular 5-HT back into the cytoplasm (Iversen, 1971; Blakely et al., 1991; Rudnick and Clark, 1993; Torres et al., 2003; Murphy et al., 2004) resulting in termination of 5-HT neurotransmission and preventing extrasynaptic transmission (Blakely et al., 1991; Schloss et al., 1992; Lesch et al., 1993). The regulation of serotonergic signaling by SERTs plays a key role in the regulation and the functioning of the serotonergic system in locomotion (Hayashi et al., 2010; Husch et al., 2012).

Various allosteric modulators of SERTs are currently gaining significant clinical importance as a way to enhance the functional capacity of these transport proteins when concentrations of 5HT are rate limiting, such as observed following SCI. Work conducted by Hayashi et al. (2010) has suggested that even if 5-HT receptors are up-regulated following spinal cord transection and are thus available for the generation of locomotion when activated by specific agonists, the same approach may not be as effective in improving locomotor function in incomplete SCI models, such as a spinal cord contusion. Though spared supraspinal serotonergic projections are retained after incomplete SCI, there appears to be an absence of 5-HT receptor activation, despite an enhanced upregulation of $5-\mathrm{HT}_{2} \mathrm{C}$ receptors caudal to the injury. It was shown in this study that the administration of selective $5-\mathrm{HT}_{2 \mathrm{C}}$ or $5-\mathrm{HT}_{1 \mathrm{~A}}$ receptor agonists, either alone or in combination after contusive SCI, was unable to produce receptor activation as evidenced from a lack of improvement in hind limb motor function. An improvement in motor function was only observed when there was broad receptor activation produced by the administration of the 5-HT precursor, 5-hydroxytryptophan (L-5-HTP), suggesting that an elevation in the levels of serotonergic receptors alone may not be sufficient to promote an improvement in motor function in models of incomplete injury. Even though there are spared serotonergic axons that are retained after contusive SCI, it has been suggested that they may have impaired function due to a dramatic reduction in the levels of SERTs, resulting in a dysregulation of 5-HT reuptake (Husch et al., 2012). Therefore prominent loss of SERT may be the causative reason for a reduced ability of the 5-HT agonists to improve locomotor outcome after an incomplete injury, indicating SERT as a critical limiting factor that is necessary to overcome locomotor impairment following SCI. Work to transgenetically overexpress SERTs in animals receiving SCI and the administration of selective $5-\mathrm{HT}_{1}$ and $5-\mathrm{HT}_{2}$ agonists would provide strong evidence for a role of SERTs in both SCI-mediated locomotor dysfunction and as a therapeutic modality for facilitating locomotor output.

\section{TRANSPLANTATION PARADIGMS INVOLVING THE DELIVERY OF 5-HT EXPRESSING CELLS TO IMPROVE LOCOMOTOR OUTCOME AFTER SCI}

Although a number of pharmacological approaches have been employed to activate the CPG to induce locomotion in models of SCI with varying degrees of success as described above, an alternative has been to introduce cells into the injured spinal cord that are capable of producing 5-HT. These exogenous 5-HT expressing cells can be used to replace the loss of monoaminergic supraspinal afferents and serve as a relay to restore serotonergic projections caudal to the level of the injury (Bregman, 1994). One such cell type that has been employed for this purpose is embryonic brainstem neurons or raphe neurons, which are able to extend serotonergic axons into adjacent host spinal tissue to deliver 5-HT following transplantation at, or below, the level of the injury (Privat et al., 1989; Rajaofetra et al., 1989a, 1992b; Gimenez y Ribotta et al., 1998; Ribotta et al., 2000). The intraspinal transplantation of these cells has been shown to reverse SCI-induced changes in 5-HT receptor densities and to restore hind limb weight support and locomotor activity on a treadmill, without the need for additional pharmacological interventions (Gimenez y Ribotta et al., 1996). Studies carried out by Feraboli-Lohnherr et al. (1997), employing the transplantation of embryonic brainstem neurons within the transected thoracic cord of chronically injured rats, showed that these neurons were able to provide serotonergic innervation to the lumbar cord. The projections from the transplanted brainstem neurons successfully activated the CPG to facilitate locomotor activity and this effect was further improved when a 5-HT re-uptake inhibitor was introduced. Majczyński et al. (2005) performed grafting of embryonic raphe nuclei cells into the spinal cord at T12, below the level of a complete spinal cord transection at T9 in adult rats at 1 month post injury and showed that hind limb locomotor function could be restored. The transected animals receiving the cell grafts, when placed on a treadmill, were able to walk with regular, alternating hind limb movements and exhibited plantar contact with the ground during the stance phase as well as ankle dorsiflexion during the swing phase of each step cycle. These behaviors were not observed in the injured control animals that did not receive the grafts and reflected the establishment of new serotonergic innervation to the caudal cord by the grafted neurons. The observed improvement in locomotor activity with embryonic raphe nuclei cell grafts could be reduced in the presence of the 5$\mathrm{HT}_{2}$ antagonist cyproheptadine, and the loss of function regained with the $5-\mathrm{HT}_{2}$ agonist quipazine, suggesting a $5-\mathrm{HT}_{2}$ receptor mediated effect.

A similar improvement in locomotor performance was observed when embryonic raphe cells were transplanted into the spinal cord of chronically injured rats that had received a transection SCI at either T9 or T11 (Gimenez y Ribotta et al., 1996). The degree of locomotor recovery correlated to the level at which the SCI or the transplant were made, with a better outcome observed when these were performed at the T11 level, rather than 
T9, due to the closer proximity to the lumbar CPG and a greater degree of serotonergic axon reinnervation of the lumbar cord. Later work showed that with this approach, greater efficacy for restoring locomotor activity could be obtained when embryonic serotonergic neuron transplantation after SCI was performed even closer to the CPG, at the level of lumbo-sacral spinal cord (Orsal et al., 2002). In addition to using brainstem neurons, Eaton et al. (2008) used the transplantation of hNT2.19 cells, a human neuronal cell line differentiated to serotonergic neurons capable of secreting 5-HT, into the severely contused spinal cord of rats 1 week after SCI to restore serotonergic neurotransmission. When employed with the combination of environmental enrichment, a significant improvement in locomotor function was observed, including reductions in foot exo-rotation and footfall errors on a gridwalk test. Recently, Sławińska et al. (2013) intraspinally grafted E14 fetal neurons obtained from the medulla, containing the B1, B2 and B3 serotonergic regions, which constitutes all the likely sources of descending 5 -HT tracts from the caudal brainstem, after SCI. These fetal neurons were grafted at the T10/11 vertebra level of adult rats with a complete spinal cord transection at the T9/10 level and were shown to successfully restore coordinated plantar stepping and improve intra- and interlimb coordination. Using pharmacological antagonists, it was further demonstrated that the transplants mediated their effects through the activation of $5-\mathrm{HT}_{7}$ and $5-\mathrm{HT}_{2}$ receptors localized to different populations of spinal neurons. Furthermore, even when these neurons were transplanted at 1 month post-SCI there was a restoration of coordinated hind limb function evoked in response to tail stimulation.

Studies employing cellular therapies to replace lost 5-HT projections to regions below the level of the lesion, particularly to the $\mathrm{CPG}$, provide a promising means for restoring locomotion after SCI. At the same time, this approach may be able to overcome some of the limitations that might be anticipated with a pharmacological based strategy, such as a lack of persistent activation of 5-HT receptors as a result of receptor desensitization to prolonged agonist exposure (Kelly et al., 2008) or side effects associated with the systemic administration of these drugs (Sławińska et al., 2013). Studies have begun to examine feasible sources of serotonergic neurons that could be used for transplantation paradigms, particularly the use of induced pluripotent stem cell (IPSC) and transcription factor cocktails for the generation of these neurons from either fibroblasts or embryonic stem cells (Shimada et al., 2012). It remains to be determined whether these cells can be used to promote improved locomotor output after SCI when employed in the same experimental paradigms where embryonic brainstem neurons have demonstrated benefit.

\section{CELL THERAPEUTIC STRATEGIES TO PROMOTE REGENERATION OF SEROTONERGIC AXONS AND FUNCTIONAL RECOVERY AFTER SCI}

Though there are adaptive mechanisms of endogenous plasticity within the injured spinal cord and reorganization at the level of the brain that compensates for the loss of transmission from multiple descending pathways (Hawthorne et al., 2011; Zörner et al., 2014), with severe injuries such mechanisms are not able to reverse paralysis and restore locomotor function without the use of additional therapeutic interventions. In experimental SCI paradigms a range of therapeutic approaches have been shown to limit tissue damage, promote axon growth and plasticity and improve the degree of functional recovery (Pearse et al., 2004; Boulenguez and Vinay, 2009). Of the most effective approaches to improve locomotor outcome after SCI, many have demonstrated a significant enhancement of growth and regeneration of descending serotonergic axons caudal to the lesion site (Menei et al., 1998; Tobias et al., 2003; Pearse et al., 2004; Ramer et al., 2004; Oatway et al., 2005; Boido et al., 2009; Ghosh et al., 2012; Hodgetts et al., 2013; Hou et al., 2013; Kanno et al., 2014). It has been shown in different SCI models, in mice and rats, that there is some degree of endogenous axon growth/sprouting of serotonergic axons that occurs (Bregman et al., 1997; RamónCueto et al., 1998), though the extent of such growth is only short distance (Bregman et al., 1997) unless an exogenous strategy is employed. The use of cell therapeutic approaches (Tetzlaff et al., 2011), such as the implantation of olfactory ensheathing cells (OECs) in rats with a complete transection SCI and Schwann cell (SC) bridging, has shown that significant long distance regeneration of serotonergic axons across a bridged SCI gap and into the contiguous caudal cord can be obtained (Ramón-Cueto et al., 2000); similar findings with OECs have been reported in other SCI paradigms (Lu et al., 2002; Plant et al., 2003). Though rats receiving OECs did exhibit modest improvements in hind limb function, they were unable to recover weight bearing capacity ( $\mathrm{Lu}$ et al., 2002) and other neuronal populations, such as those of the corticospinal tract, failed to regenerate. Recently, Barbour et al. (2013) transplanted OEG and SCs sub-acutely, at 2 weeks, following spinal cord contusion in rat and reported an improvement in locomotor function that was accompanied by the growth of supraspinal projections originating from brainstem serotonergic regions.

The transplantation of genetically modified SCs, to secrete brain derived neurotrophic factor (BDNF; Menei et al., 1998) or D15A (Golden et al., 2007; Flora et al., 2013), a bifunctional neurotrophic molecule capable of activating both TrkB and $\mathrm{C}$ receptors, in transection or contusion SCI, respectively, have been shown also to promote considerable serotonergic axon regeneration at, and/or beyond, the injury level. Similarly, we have shown that genetic engineering of SCs, to enhance surface polysialic acid (PSA), also enhances their ability to support serotonergic growth across the lesion site and improve locomotor function when the SCs are transplanted into the contused spinal cord of rats (Ghosh et al., 2012). Recent work by Hodgetts et al. (2013) has reported that the transplantation of human mesenchymal precursor cells (Stro- ${ }^{+}$), obtained from SCI patients can improve functional recovery and tissue sparing in athymic nude rats subjected to a $200 \mathrm{kDyne}$ contusion injury at the vertebral level of T9-T10. The promotion of significant serotonergic axon growth within and surrounding the transplanted cells was a key anatomical change, although evidence of these 5-HT axons reaching the CPG in the caudal cord was not investigated.

The use of cell grafts, not only as a source of serotonergic neurons to provide direct input to the CPG but also as a substrate for supporting the growth of severed supraspinal serotonergic 
projections across the lesion to reinnervate the CPG, have thus shown potential for restoring locomotor function after SCI. Further enhancement of these approaches with regenerative factors to encourage greater axon growth into the caudal cord or with agonists of monoaminergic systems to enhance the functionality of caudal projections, may be able to provide more robust strategies for the recovery of function after SCI in which the spinal cord CPG remains intact.

\section{CONCLUSION}

The serotonergic pathway works in concert with other monoaminergic systems in the synaptic control of motoneuron excitability. 5-HT contributes to the initiation of locomotion and other rhythmic motor behaviors as well as to the modulation of synaptic transmission in specific reflex pathways through its action on presynaptic terminals. Binding of 5-HT to specific receptor subtypes is responsible for initiating diverse intracellular signaling cascades that can alter the properties of ligand gated voltage-sensitive ion channels and produce a subsequent rapid depolarization of the postsynaptic membrane potential of target neurons to increase their intrinsic excitability. One of the major changes that occurs after SCI is the loss of most, if not all, of the descending monoaminergic input to the spinal cord below the level of the lesion, particularly to the spinal CPG, resulting in immediate and persistent locomotor dysfunction. Although axotomized serotonergic axons have the capacity to undergo sprouting after SCI, endogenous recovery of locomotor function is limited.

Substantial progress has been made in our understanding of the roles of the diverse number of 5-HT receptor subtypes and how they coordinate with one another and receptor signaling through other monoaminergic systems to alter motor output following SCI. The use of either pharmacological or cellular approaches to modulate the activity of various receptor subtypes in response to 5 - $\mathrm{HT}$ or to provide $5-\mathrm{HT}$ input caudal to the lesion site, respectively, have shown that the restoration of serotonergic signaling can be an effective means for promoting motoneuron excitability and restoring locomotor function after SCI. The use of genetic tools to investigate the role of specific 5-HT receptors in different aspects of motor output or in understanding the role of regenerating serotonergic axons in functional efficacy provided by different therapeutic modalities remains limited and should receive greater attention in future research.

Approaches to restore function after SCI through targeting 5-HT have shown some degree of success, however, a number of limitations remain to be resolved and questions answered. Though the use of 5-HT or specific 5-HT receptor agonists can stimulate CPG neuronal networks and induce locomotion, it is not clear whether such an approach can be employed for sustained functional recovery in light of receptor desensitization and/or loss of responses to the stimuli over time, a common phenomenon with GPCR family members. One strategy for achieving a sustained functional improvement using physiological levels of 5-HT could be through cellular therapies, where serotonergic neurons generated from various sources could be used to replace lost supraspinal serotonergic projections to the
CPG below the level of SCI. Not only does a cell therapeutic approach eliminate the risk of side effects associated with systemic administration of high levels of 5-HT receptor agonists but also allows intraspinal delivery of 5-HT directly to where it is required after potentially a single intervention. Alternatively, the use of cell transplants, in combination with proregenerative therapies, can be used to bridge the injury site and provide a substrate for severed serotonergic axons to regrow to their original caudal targets. Though the robustness and applicability of such approaches to a variety of SCI paradigms and injury levels has not yet been thoroughly investigated and many cell transplantation strategies to date have failed to promote the growth of serotonergic axons in significant numbers beyond the lesion into the contiguous caudal cord let alone beyond to the lumbar CPG. Another issue with cell therapeutic approaches is their limited long-term cell survival following transplantation due to the inflammatory environment of the injured spinal cord and rejection, potentially reducing their effectiveness in maintaining functional improvements over time. Therefore, extensive optimization of various cell therapeutic approaches is currently a priority in the field to maximize their therapeutic efficacy.

Another promising strategy to induce locomotor function after SCI in combination with 5-HT or its receptor agonists involves the activation of spinal locomotor networks via EES and data so far are encouraging, both in experimental SCI paradigms and clinically in complete SCI individuals. Similar to the use of pharmacological approaches alone is whether such a combination strategy can be implemented for the persistent restoration of function and whether additional interventions, including cell transplants, can enhance or prolong the benefits of this strategy. Further research at the molecular, cellular and functional level to trigger the necessary sequence of neurological events for complete restoration of locomotor function after human SCI continues to remain as a major challenge and a research area of primary focus. The promotion or facilitation of serotonergic signaling, so as to enhance motoneuron excitability, stimulate CPG activity and restore locomotor function, is one direction at the forefront of research for generating putative interventional approaches for the treatment of SCI.

\section{REFERENCES}

Agnati, L. F., Fuxe, K., Zoli, M., Ozini, I., Toffano, G., and Ferraguti, F. (1986). A correlation analysis of the regional distribution of central enkephalin and beta-endorphin immunoreactive terminals and of opiate receptors in adult and old male rats. Evidence for the existence of two main types of communication in the central nervous system: the volume transmission and the wiring transmission. Acta Physiol. Scand. 128, 201-207. doi: 10.1111/j.1748-1716.1986. tb07967.x

Angeli, C. A., Edgerton, V. R., Gerasimenko, Y. P., and Harkema, S. J. (2014). Altering spinal cord excitability enables voluntary movements after chronic complete paralysis in humans. Brain 137, 1394-1409. doi: 10.1093/brain/ awu038

Antri, M., Mouffle, C., Orsal, D., and Barthe, J. Y. (2003). 5-HT1A receptors are involved in short- and long-term processes responsible for 5-HT-induced locomotor function recovery in chronic spinal rat. Eur. J. Neurosci. 18, 19631972. doi: 10.1046/j.1460-9568.2003.02916.x

Antri, M., Orsal, D., and Barthe, J. Y. (2002). Locomotor recovery in the chronic spinal rat: effects of long-term treatment with a 5-HT2 agonist. Eur. J. Neurosci. 16, 467-476. doi: 10.1046/j.1460-9568.2002.02088.x 
Azmitia, E. C. (1999). Serotonin neurons, neuroplasticity, and homeostasis of neural tissue. Neuropsychopharmacology 21, 33S-45S. doi: 10.1016/S0893133X(99)00022-6

Azmitia, E. C., and Gannon, P. J. (1986). The primate serotonergic system: a review of human and animal studies and a report on macaca fasicularis. Adv. Neurol. $43,407-468$.

Bach-y-Rita, P. (1999). Theoretical aspects of sensory substitution and of neurotransmission-related reorganization in spinal cord injury. Spinal Cord 37, 465-474. doi: 10.1038/sj.sc.3100873

Ballion, B., Branchereau, P., Chapron, J., and Viala, D. (2002). Ontogeny of descending serotonergic innervation and evidence for intraspinal 5-HT neurons in the mouse spinal cord. Brain Res. Dev. Brain Res. 137, 81-88. doi: 10. 1016/s0165-3806(02)00414-5

Barbour, H. R., Plant, C. D., Harvey, A. R., and Plant, G. W. (2013). Tissue sparing, behavioral recovery, supraspinal axonal sparing/regeneration following subacute glial transplantation in a model of spinal cord contusion. BMC Neurosci. 14:106. doi: 10.1186/1471-2202-14-106

Bayliss, D. A., Umemiya, M., and Berger, A. J. (1995). Inhibition of N- and Ptype calcium currents and the after-hyperpolarization in rat motoneurones by serotonin. J. Physiol. (Lond.) 485, 635-647. doi: 10.1113/jphysiol.1995.sp020758

Beliez, L., Barrière, G., Bertrand, S. S., and Cazalets, J. R. (2014). Multiple monoaminergic modulation of posturo-locomotor network activity in the newborn rat spinal cord. Front. Neural Circuits 8:99. doi: 10.3389/fncir.2014. 00099

Blakely, R. D., Berson, H. E., Fremeau, R. T. Jr., Caron, M. G., Peek, M. M., Prince, H. K., et al. (1991). Cloning and expression of a functional serotonin transporter from rat brain. Nature 354, 66-70. doi: 10.1038/354066a0

Bobker, D. H., and Williams, J. T. (1990). Serotonin-mediated inhibitory postsynaptic potential in guinea-pig prepositus hypoglossi and feedback inhibition by serotonin. J. Physiol. 422, 447-462. doi: 10.1113/jphysiol.1990.sp017994

Boido, M., Rupa, R., Garbossa, D., Fontanella, M., Ducati, A., and Vercelli, A. (2009). Embryonic and adult stem cells promote raphespinal axon outgrowth and improve functional outcome following spinal hemisection in mice. Eur. J. Neurosci. 30, 833-846. doi: 10.1111/j.1460-9568.2009.06879.x

Boulenguez, P., Liabeuf, S., Bos, R., Bras, H., Jean-Xavier, C., Brocard, C., et al. (2010). Downregulation of the potassium-chloride cotransporter KCC2 contributes to spasticity after spinal cord injury. Nat. Med. 16, 302-307. doi: 10. 1038/nm.2107

Boulenguez, P., and Vinay, L. (2009). Strategies to restore motor functions after spinal cord injury. Curr. Opin. Neurobiol. 19, 587-600. doi: 10.1016/j.conb.2009. 10.005

Branchereau, P., Chapron, J., and Meyrand, P. (2002). Ending 5-hydroxytryptamine raphe inputs repress the expression of serotonergic neurons and slow the maturation of inhibitory systems in mouse embryonic spinal cord. J. Neurosci. 22, 2598-2606.

Bregman, B. S. (1994). "Recovery of function after spinal cord injury: transplantation strategies," in Functional Neural Transplantation, eds S. B. Dunnett and A. Bjorklund (New York: Raven), 489-529.

Bregman, B. S., Coumans, J. V., Dai, H. N., Kuhn, P. L., Lynskey, J., McAtee, M., et al. (2002). Transplants and neurotrophic factors increase regeneration and recovery of function after spinal cord injury. Prog. Brain Res. 137, 257-273. doi: 10.1016/s0079-6123(02)37020-1

Bregman, B. S., McAtee, M., Dai, H. N., and Kuhn, P. L. (1997). Neurotrophic factors increase axonal growth after spinal cord injury and transplantation in the adult rat. Exp. Neurol. 148, 475-494. doi: 10.1006/exnr.1997.6705

Brustein, E., and Rossignol, S. (1999). Recovery of locomotion after ventral and ventrolateral spinal lesions in the cat. II. Effects of noradrenergic and serotoninergic drugs. J. Neurophysiol. 81, 1513-1530.

Carlsson, A., Magnusson, T., and Rosengren, E. (1963). 5-Hydroxytryptamine of the spinal cord normally and after transection. Experimentia 19, 359-406. doi: $10.1007 / \mathrm{bf} 02152316$

Cazalets, J. R., Sqalli-Houssaini, Y., and Clarac, F. (1992). Activation of the central pattern generators for locomotion by serotonin and excitatory amino acids in neonatal rat. J. Physiol. 455, 187-204. doi: 10.1113/jphysiol.1992. sp019296

Clineschmidt, B. V., Pierce, J. E., and Lovenberg, W. (1971). Tryptophan hydroxylase and serotonin in spinal cord and brain stem before and after chronic transection. J. Neurochem. 18, 1593-1596. doi: 10.1111/j.1471-4159.1971. tb00021.x
Cornide-Petronio, M. E., Fernández-López, B., Barreiro-Iglesias, A., and Rodicio, M. C. (2014). Traumatic injury induces changes in the expression of the serotonin 1A receptor in the spinal cord of lampreys. Neuropharmacology 77, 369-378. doi: 10.1016/j.neuropharm.2013.10.017

Courtine, G., Gerasimenko, Y., Van den Brand, R., Yew, A., Musienko, P., Zhong, H., et al. (2009). Transformation of nonfunctional spinal circuits into functional states after the loss of brain input. Nat. Neurosci. 12, 1333-1342. doi: 10.1038/nn. 2401

Dahlstroem, A., and Fuxe, K. (1964). Evidence for the existence of monoamine containing neurons in the central nervous system. I. Demonstration of monamines in the cell bodies of brain stem neurons. Acta Physiol. Scand. Suppl. 62(Suppl. 232), 1-55.

D’Amico, J. M., Condliffe, E. G., Martins, K. J., Bennett, D. J., and Gorassini, M. A. (2014). Recovery of neuronal and network excitability after spinal cord injury and implications for spasticity. Front. Integr. Neurosci. 8:36. doi: 10.3389/fnint. 2014.00036

Dimitrijevic, M. R., Gerasimenko, Y., and Pinter, M. M. (1998). Evidence for a spinal central pattern generator in humans. Ann. N Y Acad. Sci. 860, 360-376. doi: 10.1111/j.1749-6632.1998.tb09062.x

Di Pasquale, E., Lindsay, A. D., Feldman, J. L., Monteau, R., and Hilaire, G. (1997). Serotonergic inhibition of phrenic motoneuron activity: an in vitro study in neonatal rat. Neurosci. Lett. 230, 29-32. doi: 10.1016/s0304-3940(97)00469-2

Eaton, M. J., Pearse, D. D., McBroom, J. S., and Berrocal, Y. A. (2008). The combination of human neuronal serotonergic cell implants and environmental enrichment after contusive SCI improves motor recovery over each individual strategy. Behav. Brain Res. 194, 236-241. doi: 10.1016/j.bbr.2008.07.001

El Manira, A. (2014). Dynamics and plasticity of spinal locomotor circuits. Curr. Opin. Neurobiol. 29C, 133-141. doi: 10.1016/j.conb.2014.06.016

Engesser-Cesar, C., Ichiyama, R. M., Nefas, A. L., Hill, M. A., Edgerton, V. R., Cotman, C. W., et al. (2007). Wheel running following spinal cord injury improves locomotor recovery and stimulates serotonergic fiber growth. Eur. J. Neurosci. 25, 1931-1939. doi: 10.1111/j.1460-9568.2007.05469.x

Feraboli-Lohnherr, D., Barthe, J. Y., and Orsal, D. (1999). Serotonin-induced activation of the network for locomotion in adult spinal rats. J. Neurosci. Res. 55, 87-98. doi: 10.1002/(sici) 1097-4547(19990101)55:1<87::aid-jnr10>3.3.co;2-r

Feraboli-Lohnherr, D., Orsal, D., Yakovleff, A., Giménez y Ribotta, M., and Privat, A. (1997). Recovery of locomotor activity in the adult chronic spinal rat after sublesional transplantation of embryonic nervous cells: specific role of serotonergic neurons. Exp. Brain Res. 113, 443-454. doi: 10.1007/pl00005597

Filli, L., Engmann, A. K., Zörner, B., Weinmann, O., Moraitis, T., Gullo, M., et al. (2014). Bridging the gap: a reticulo-propriospinal detour bypassing an incomplete spinal cord injury. J. Neurosci. 34, 13399-13410. doi: 10.1523/jneurosci. 0701-14.2014

Flora, G., Joseph, G., Patel, S., Singh, A., Bleicher, D., Barakat, D. J., et al. (2013). Combining neurotrophin-transduced Schwann cells and rolipram to promote functional recovery from subacute spinal cord injury. Cell Transplant. 22, 22032217. doi: $10.3727 / 096368912 \times 658872$

Fornal, C. A., Litto, W. J., Metzler, C. W., Marrosu, F., Tada, K., and Jacobs, B. L. (1994). Single-unit responses of serotonergic dorsal raphe neurons to 5-HT1A agonist and antagonist drug administration in behaving cats. J. Pharmacol. Exp. Ther. 270, 1345-1358.

Fouad, K., Rank, M. M., Vavrek, R., Murray, K. C., Sanelli, L., and Bennett, D. J. (2010). Locomotion after spinal cord injury depends on constitutive activity in serotonin receptors. J. Neurophysiol. 104, 2975-2984. doi: 10.1152/jn.00499. 2010

Fuller, D. D., Baker-Herman, T. L., Golder, F. J., Doperalski, N. J., Watters, J. J., and Mitchell, G. S. (2005). Cervical spinal cord injury upregulates ventral spinal 5-HT2A receptors. J. Neurotrauma 22, 203-213. doi: 10.1089/neu.2005. 22.203

Gackière, F., and Vinay, L. (2014). Serotonergic modulation of post-synaptic inhibition and locomotor alternating pattern in the spinal cord. Front. Neural Circuits 8:102. doi: 10.3389/fncir.2014.00102

Garcia-Rill, E., Skinner, R. D., and Fitzgerald, J. A. (1985). Chemical activation of the mesencephalic locomotor region. Brain Res. 330, 43-54. doi: 10.1016/00068993(85)90006-x

Gerasimenko, Y. P., Ichiyama, R. M., Lavrov, I. A., Courtine, G., Cai, L., Zhong, H., et al. (2007). Epidural spinal cord stimulation plus quipazine administration enable stepping in complete spinal adult rats. J. Neurophysiol. 98, 2525-2536. doi: $10.1152 /$ in. 00836.2007 
Gerin, C. G., Hill, A., Hill, S., Smith, K., and Privat, A. (2010). Serotonin release variations during recovery of motor function after a spinal cord injury in rats. Synapse 64, 855-861. doi: 10.1002/syn.20802

Gerin, C., Teilhac, J. R., Smith, K., and Privat, A. (2008). Motor activity induces release of serotonin in the dorsal horn of the rat lumbar spinal cord. Neurosci. Lett. 436, 91-95. doi: 10.1016/j.neulet.2008.01.081

Ghosh, A., Sydekum, E., Haiss, F., Peduzzi, S., Zörner, B., Schneider, R., et al. (2009). Functional and anatomical reorganization of the sensory-motor cortex after incomplete spinal cord injury in adult rats. J. Neurosci. 29, 12210-12219. doi: 10.1523/jneurosci.1828-09.2009

Ghosh, M., Tuesta, L. M., Puentes, R., Patel, S., Melendez, K., El Maarouf, A., et al. (2012). Extensive cell migration, axon regeneration and improved function with polysialic acid-modified Schwann cells after spinal cord injury. Glia 60, 979-992. doi: 10.1002/glia.22330

Gimenez y Ribotta, M., Orsal, D., Feraboli-Lohnherr, D., Privat, A., Provencher, J., and Rossignol, S. (1998). Kinematic analysis of recovered locomotor movements of the hindlimbs in paraplegic rats transplanted with monoaminergic embryonic neurons. Ann. N Y Acad. Sci. 860, 521-523. doi: 10.1111/j.1749-6632.1998. tb09093.x

Gimenez y Ribotta, M. G., Roudet, C., Sandillon, F., and Privat, A. (1996). Transplantation of embryonic noradrenergic neurons in two models of adult rat spinal cord injury: ultrastructural immunocytochemical study. Brain Res. 707, 245-255. doi: 10.1016/0006-8993(95)01266-4

Golden, K. L., Pearse, D. D., Blits, B., Garg, M. S., Oudega, M., Wood, P. M., et al. (2007). Transduced Schwann cells promote axon growth and myelination after spinal cord injury. Exp. Neurol. 207, 203-217. doi: 10.1016/j.expneurol.2007.06. 023

Grillner, S. (2006). Biological pattern generation: the cellular and computational logic of networks in motion. Neuron 5, 751-766. doi: 10.1016/j.neuron.2006.11. 008

Grillner, S., and Walleń, P. (1985). Central pattern generators for locomotion, with special reference to vertebrates. Annu. Rev. Neurosci. 8, 233-261. doi: 10. 1146/annurev.neuro.8.1.233

Guertin, P. A., and Steuer, I. (2005). Ionotropic 5-HT3 receptor agonist-induced motor responses in the hindlimbs of paraplegic mice. J. Neurophysiol. 94, 33973405. doi: 10.1152/jn.00587.2005

Harkema, S., Gerasimenko, Y., Hodes, J., Burdick, J., Angeli, C., Chen, Y., et al. (2011). Effect of epidural stimulation of the lumbosacral spinal cord on voluntary movement, standing and assisted stepping after motor complete paraplegia: a case study. Lancet 377, 1938-1947. doi: 10.1016/S0140-6736(11) 60547-3

Harris-Warrick, R. M., and Cohen, A. H. (1985). Serotonin modulates the central pattern generator for locomotion in the isolated lamprey spinal cord. J. Exp. Biol. $116,27-46$.

Harvey, P. J., Li, X., Li, Y., and Bennett, D. J. (2006). 5-HT 2 Receptor activation facilitates a persistent sodium current and repetitive firing in spinal motoneurons of rats with and without chronic spinal cord injury. J. Neurophysiol. 96, 1158-1170. doi: 10.1152/jn.01088.2005

Hasegawa, Y., and Ono, H. (1996). Effects of 8-OH-DPAT, a 5-HT1Areceptor agonist and DOI, a 5-HT2A/2C agonist, on monosynaptic transmission in spinalized rats. Brain Res. 738, 158-161. doi: 10.1016/0006-8993(96)00991-2

Hashimoto, T., and Fukuda, N. (1991). Contribution of serotonin neurons to the functional recovery after spinal cord injury in rats. Brain Res. 539, 263-270. doi: 10.1016/0006-8993(91)91630-j

Hawthorne, A. L., Hu, H., Kundu, B., Steinmetz, M. P., Wylie, C. J., Deneris, E. S., et al. (2011). The unusual response of serotonergic neurons after CNS injury: lack of axonal dieback and enhanced sprouting within the inhibitory environment of the glial scar. J. Neurosci. 31, 5605-5616. doi: 10.1523/jneurosci. 6663-10.2011

Hayashi, Y., Jacob-Vadakot, S., Dugan, E. A., McBride, S., Olexa, R., Simansky, K., et al. (2010). 5-HT precursor loading, but not 5-HT receptor agonists, increases motor function after spinal cord contusion in adult rats. Exp. Neurol. 221, 68-78. doi: 10.1016/j.expneurol.2009.10.003

Hentall, I. D., Pinzon, A., and Noga, B. R. (2006). Spatial and temporal patterns of serotonin release in the rat's lumbar spinal cord following electrical stimulation of the nucleus raphe magnus. Neuroscience 142, 893-903. doi: 10.1016/j. neuroscience.2006.06.038

Herrick-Davis, K. (2013). Functional significance of serotonin receptor dimerization. Exp. Brain Res. 230, 375-386. doi: 10.1007/s00221-013-3622-1
Hikosaka, O. (2007). GABAergic output of the basal ganglia. Prog. Brain Res. 160, 209-226. doi: 10.1016/s0079-6123(06)60012-5

Hochman, S., Garraway, S. M., Machacek, D. W., and Shay, B. L. (2001). "5-HT receptors and the neuromodulatory control of spinal cord function," in Motor Neurobiology of the Spinal Cord, ed T. C. Cope (London: CRC Press), 47-87.

Hodgetts, S. I., Simmons, P. J., and Plant, G. W. (2013). A comparison of the behavioral and anatomical outcomes in sub-acute and chronic spinal cord injury models following treatment with human mesenchymal precursor cell transplantation and recombinant decorin. Exp. Neurol. 248, 343-359. doi: 10. 1016/j.expneurol.2013.06.018

Holmes, G. M., Van Meter, M. J., Beattie, M. S., and Bresnahan, J. C. (2005). Serotonergic fiber sprouting to external anal sphincter motoneurons after spinal cord contusion. Exp. Neurol. 193, 29-42. doi: 10.1016/j.expneurol.2005. 01.002

Holtmanj, J. R. Jr., Dickt, T. E., and Bergera, A. J. (1986). Involvement of serotonin in the excitation of phrenic motoneurons evoked by stimulation of the raphe obscurus. J. Neurosci. 6, 1185-1193.

Hornung, J. P. (2003). The human raphe nuclei and the serotonergic system. J. Chem. Neuroanat. 26, 331-343. doi: 10.1016/j.jchemneu.2003.10.002

Hou, S., Tom, V. J., Graham, L., Lu, P., and Blesch, A. (2013). Partial restoration of cardiovascular function by embryonic neural stem cell grafts after complete spinal cord transection. J. Neurosci. 33, 17138-17149. doi: 10.1523/jneurosci. 2851-13.2013

Hounsgaard, J., Hultborn, H., Jespersen, B., and Kiehn, O. (1988). Bistability of alpha-motoneurones in the decerebrate cat and in the acute spinal cat after intravenous 5-hydroxytryptophan. J. Physiol. 405, 345-367. doi: 10. 1113/jphysiol.1988.sp017336

Humphreys, J. M., and Whelan, P. J. (2012). Dopamine exerts activation-dependent modulation of spinal locomotor circuits in the neonatal mouse. J. Neurophysiol. 108, 3370-3381. doi: 10.1152/jn.00482.2012

Husch, A., Van Patten, G. N., Hong, D. N., Scaperotti, M. M., Cramer, N., and Harris-Warrick, R. M. (2012). Spinal cord injury induces serotonin supersensitivity without increasing intrinsic excitability of mouse V2a interneurons. $J$. Neurosci. 32, 13145-13154. doi: 10.1523/jneurosci.2995-12.2012

Ichiyama, R. M., Gerasimenko, Y. P., Zhong, H., Roy, R. R., and Edgerton, V. R. (2005). Hindlimb stepping movements in complete spinal rats induced by epidural spinal cord stimulation. Neurosci. Lett. 383, 339-344. doi: 10.1016/j. neulet.2005.04.049

Iversen, L. L. (1971). Role of transmitter uptake mechanisms in synaptic neurotransmission. Br. J. Pharmacol. 41, 571-591. doi: 10.1111/j.1476-5381.1971. tb07066.x

Iwahara, T., Atsuta, Y., Garsia-Rill, E., and Skinner, R. (1992). Spinal cord stimulation-induced locomotion in the adult cat. Brain Res. Bull. 28, 99-105. doi: 10.1016/0361-9230(92)90235-p

Jacobs, B. L., and Fornal, C. A. (1993). 5-HT and motor control: a hypothesis. Trends Neurosci. 16, 346-352. doi: 10.1016/0166-2236(93)90090-9

Johnson, D. A., Gartside, S. E., and Ingram, C. D. (2002). 5-HT1A receptormediated autoinhibition does not function at physiological firing rates: evidence from in vitro electrophysiological studies in the rat dorsal raphe nucleus. Neuropharmacology 43, 959-965. doi: 10.1016/s0028-3908(02)00116-8

Jordan, L. M., Liu, J., Hedlund, P. B., Akay, T., and Pearson, K. G. (2008). Descending command systems for the initiation of locomotion in mammals. Brain Res. Rev. 57, 183-191. doi: 10.1016/j.brainresrev.2007.07.019

Kanno, H., Pressman, Y., Moody, A., Berg, R., Muir, E. M., Rogers, J. H., et al. (2014). Combination of engineered Schwann cell grafts to secrete neurotrophin and chondroitinase promotes axonal regeneration and locomotion after spinal cord injury. J. Neurosci. 34, 1838-1855. doi: 10.1523/jneurosci.2661-13. 2014

Kelly, E., Bailey, C. P., and Henderson, G. (2008). Agonist-selective mechanisms of GPCR desensitization. Br. J. Pharmacol. 153, S379-S388. doi: 10.1038/sj.bjp. 0707604

Kiehn, O. (2006). Locomotor circuits in the mammalian spinal cord. Annu. Rev. Neurosci. 29, 279-306. doi: 10.1146/annurev.neuro.29.051605.112910

Kiehn, O., and Kullander, K. (2004). Central pattern generators deciphered by molecular genetics. Neuron. 41, 317-321. doi: 10.1016/s0896-6273(04)00042-x

Kim, D., Murray, M., and Simansky, K. J. (2001a). The serotonergic 5-HT (2C) agonist $\mathrm{m}$-chlorophenylpiperazine increases weight-supported locomotion without development of tolerance in rats with spinal transections. Exp. Neurol. 169, 496500. doi: 10.1006/exnr.2001.7660 
Kim, D., Schallert, T., Liu, Y., Browarak, T., Nayeri, N., Tessler, A., et al. (2001b). Transplantation of genetically modified fibroblast expressing BDNF in adult rats with subtotal hemisection improves specific motor and sensory functions. Neurorehabil. Neural Repair 15, 141-150. doi: 10.1177/154596830101 500207

Kong, X. Y., Wienecke, J., Chen, M., Hultborn, H., and Zhang, M. (2011). The time course of serotonin $2 \mathrm{~A}$ receptor expression after spinal transection of rats: an immunohistochemical study. Neuroscience 177, 114-126. doi: 10.1016/j. neuroscience.2010.12.062

Kong, X. Y., Wienecke, J., Hultborn, H., and Zhang, M. (2010). Robust upregulation of serotonin 2A receptors after chronic spinal transection of rats: an immunohistochemical study. Brain Res. 1320, 60-68. doi: 10.1016/j.brainres. 2010.01.030

Lalley, P. M. (1986). Serotoninergic and non-serotoninergic responses of phrenic motoneurones to raphe stimulation in the cat. J. Physiol. 380, 373-385. doi: 10. 1113/jphysiol.1986.sp016291

Lambe, E. K., Fillman, S. G., Webster, M. J., and Weickert, S. C. (2011). Serotonin receptor expression in human prefrontal cortex: balancing excitation and inhibition across postnatal development. PLoS One 6:e22799. doi: 10.1371/journal. pone.0022799

Landry, E. S., and Guertin, P. A. (2004). Differential effects of 5-HT1 and 5-HT2 receptor agonists on hindlimb movements in paraplegic mice. Prog. NeuroPsychopharmacol. Biol. Psychiatry 28, 1053-1060. doi: 10.1016/j.pnpbp.2004. 05.001

Landry, E. S., Lapointe, N. P., Rouillard, C., Levesque, D., Hedlund, P. B., and Guertin, P. A. (2006). Contribution of spinal 5-HT1A and 5-HT7 receptors to locomotor-like movement induced by 8 -OH-DPAT in spinal cordtransected mice. Eur. J. Neurosci. 24, 535-546. doi: 10.1111/j.1460-9568.2006. 04917.x

Lesch, K. P., Wolozin, B. L., Estler, H. C., Murphy, D. L., and Riederer, P. (1993). Isolation of a cDNA encoding the human brain serotonin transporter. J. Neural. Transm. Gen. Sect. 91, 67-72. doi: 10.1007/bf01244919

Levkovitz, Y., and Segal, M. (1997). Serotonin 5HTla receptors modulate hippocampal reactivity to afferent stimulation. J. Neurosci. 17, 55915598.

Li, H. J., Johnston, B., Aiello, D., Caffrey, D. R., Giel-Moloney, M., Rindi, G., et al. (2014). Distinct cellular origins for serotonin-expressing and enterochromaffinlike cells in the gastric corpus. Gastroenterology 146, 754.e3-764.e3. doi: 10 1053/j.gastro.2013.11.048

Li, X., Murray, K., Harvey, P. J., Ballou, E. W., and Bennett, D. J. (2007). Serotonin facilitates a persistent calcium current in motoneurons of rats with and without chronic spinal cord injury. J. Neurophysiol. 97, 1236-1246. doi: 10.1152/jn. 00995.2006

Liu, J., Akay, T., Hedlund, P. B., Pearson, K. G., and Jordan, L. M. (2009). Spinal 5HT7 receptors are critical for alternating activity during locomotion: in vitro neonatal and in vivo adult studies using 5-HT7 receptor knockout mice. $J$. Neurophysiol. 102, 337-348. doi: 10.1152/jn.91239.2008

Lu, J., Féron, F., Mackay-Sim, A., and Waite, P. M. (2002). Olfactory ensheathing cells promote locomotor recovery after delayed transplantation into transected spinal cord. Brain 125, 14-21. doi: 10.1093/brain/awf014

MacLean, J. N., Cowley, K. C., and Schmidt, B. J. (1998). NMDA receptor-mediated oscillatory activity in the neonatal rat spinal cord is serotonin dependent. $J$. Neurophysiol. 79, 2804-2808.

Madriaga, M. A., McPhee, L. C., Chersa, T., Christie, K. J., and Whelan, P. J. (2004). Modulation of locomotor activity by multiple 5-HT and dopaminergic receptor subtypes in the neonatal mouse spinal cord. J. Neurophysiol. 92, 1566-1576. doi: $10.1152 /$ jn. 01181.2003

Majczyński, H., Maleszak, K., Cabaj, A., and Sawińska, U. (2005). Serotoninrelated enhancement of recovery of hind limb motor functions in spinal rats after grafting of embryonic raphe nuclei. J. Neurotrauma 22, 590-604. doi: 10 . 1089/neu.2005.22.590

Martin, G. F., Cabana, T., and Humbertson, A. O. Jr. (1981). Evidence for collateral innervation of the cervical and lumbar enlargements of the spinal cord by single reticular and raphe neurons. Studies using fluorescent markers in doublelabeling experiments on the North American opossum. Neurosci. Lett. 24, 1-6. doi: 10.1016/0304-3940(81)90349-9

Martinez, M., and Rossignol, S. (2011). Changes in CNS structures after spinal cord lesions implications for BMI. Prog. Brain Res. 194, 191-202. doi: 10.1016/b978$0-444-53815-4.00007-8$
Meehan, C. F., Grondahl, L., Nielsen, J. B., and Hultborn, H. (2012). Fictive locomotion in the adult decerebrate and spinal mouse in vivo. J. Physiol. 15, 289-300. doi: 10.1113/jphysiol.2011.214643

Menei, P., Montero-Menei, C., Whittermore, S. R., Bunge, M. B., and Bunge, R. P. (1998). Schwann cells genetically engineered to produce BDNF promote axonal regeneration of brainstem neurons across transected adult rat spinal cord. Eur. J. Neurosci. 10, 607-621. doi: 10.1046/j.1460-9568.1998.00071.x

Millan, M. J., Marin, P., Bockaert, J., and Mannoury la Cour, C. (2008). Signaling at G-protein-coupled serotonin receptors: recent advances and future research directions. Trends Pharmacol. Sci. 9, 454-464. doi: 10.1016/j.tips.2008.06.007

Miller, J. F., Paul, K. D., Lee, R. H., Rymer, W. Z., and Heckman, C. J. (1996). Restoration of extensor excitability in the acute spinal cat by the 5-HT2 agonist DOI. J. Neurophysiol. 75, 620-628.

Murphy, D. L., Lerner, A., Rudnick, G., and Lesch, K. P. (2004). Serotonin transporter: gene, genetic disorders and pharmacogenetics. Mol. Interv. 4, 109-123. doi: $10.1124 / \mathrm{mi} .4 .2 .8$

Murray, K. C., Nakae, A., Stephens, M. J., Rank, M., D’Amico, J., Harvey, P. J., et al. (2010). Recovery of motoneuron and locomotor function after spinal cord injury depends on constitutive activity in 5-HT2C receptors. Nat. Med. 16, 694700. doi: $10.1038 / \mathrm{nm} .2160$

Musienko, P., van den Brand, R., Märzendorfer, O., Roy, R. R., Gerasimenko, Y., Edgerton, V. R., et al. (2011). Controlling specific locomotor behaviors through multidimensional monoaminergic modulation of spinal circuitries. J. Neurosci. 22, 9264-9278. doi: 10.1523/jneurosci.5796-10.2011

Nardone, R., Höller, Y., Thomschewski, A., Höller, P., Lochner, P., Golaszewski, S., et al. (2014). Serotonergic transmission after spinal cord injury. J. Neural Transm. doi: 10.1007/s00702-014-1241-z. [Epub ahead of print].

Navarrett, S., Collier, L., Cardozo, C., and Dracheva, S. (2012). Alterations of serotonin $2 \mathrm{C}$ and $2 \mathrm{~A}$ receptors in response to $\mathrm{T} 10$ spinal cord transection in rats. Neurosci. Lett. 506, 74-78. doi: 10.1016/j.neulet.2011.10.052

Noga, B. R., Johnson, D. M., Riesgo, M. I., and Pinzon, A. (2009). Locomotoractivated neurons of the cat. I. Serotonergic innervation and co-localization of 5-HT7, 5-HT2A and 5-HT1A receptors in the thoraco-lumbar spinal cord. J. Neurophysiol. 102, 1560-1576. doi: 10.1152/jn.91179.2008

Noga, B. R., Kriellaars, D. J., and Jordan, L. M. (1991). The effect of selective brainstem or spinal cord lesions on treadmill locomotion evoked by stimulation of the mesencephalic or pontomedullary locomotor regions. J. Neurosci. 11, $1691-1700$.

Noga, B. R., Pinzon, A., Mesigil, R. P., and Hentall, I. D. (2004). Steady-state levels of monoamines in the rat lumbar spinal cord: spatial mapping and the effect of acute spinal cord injury. J. Neurophysiol. 92, 567-577. doi: 10.1152/jn.01035. 2003

Oatway, M. A., Chen, Y., Bruce, J. C., Dekaban, G. A., and Weaver, L. C. (2005). Anti-CD11d integrin antibody treatment restores normal serotonergic projections to the dorsal, intermediate and ventral horns of the injured spinal cord. J. Neurosci. 25, 637-647. doi: 10.1523/jneurosci.3960-04.2005

Orsal, D., Barthe, J. Y., Antri, M., Feraboli-Lohnherr, D., Yakovleff, A., Giménez y Ribotta, M., et al. (2002). Locomotor recovery in chronic spinal rat: long-term pharmacological treatment or transplantation of embryonic neurons? Prog. Brain Res. 137, 213-230. doi: 10.1016/s0079-6123(02)37018-3

Otoshi, C. K., Walwyn, W. M., Tillakaratne, N. J., Zhong, H., Roy, R. R., and Edgerton, V. R. (2009). Distribution and localization of 5-HT (1A) receptors in the rat lumbar spinal cord after transection and deafferentation. J. Neurotrauma 26, 575-584. doi: 10.1089/neu.2008.0640

Pearlstein, E., Ben-Mabrouk, F., Pflieger, J. F., and Vinay, L. (2005). Serotonin refines the locomotor-related alternations in the in vitro neonatal rat spinal cord. Eur. J. Neurosci. 21, 1338-1346. doi: 10.1111/j.1460-9568.2005. 03971.x

Pearse, D. D., Pereira, F. C., Marcillo, A. E., Bates, M. L., Berrocal, Y. A., Filbin, M. T., et al. (2004). cAMP and Schwann cells promote axonal growth and functional recovery after spinal cord injury. Nat. Med. 10, 610-616. doi: 10.1038/nm 1056

Perrier, J. F., Rasmussen, H. B., Christensen, R. K., and Petersen, A. V. (2013). Modulation of the intrinsic properties of motoneurons by serotonin. Curr. Pharm. Des. 19, 4371-4384. doi: 10.2174/13816128113199990341

Perrin, F. E., Gerber, Y. N., Teigell, M., Lonjon, N., Boniface, G., Bauchet, L., et al. (2011). Anatomical study of serotonergic innervation and 5-HT (1A) receptor in the human spinal cord. Cell Death Dis. 2:e218. doi: 10.1038/cddis. 2011.98 
Pflieger, J. F., Clarac, F., and Vinay, L. (2002). Postural modifications and neuronal excitability changes induced by short-term serotonin depletion during neonatal development in the rat. J. Neurosci. 22, 5108-5117.

Plant, G. W., Christensen, C. L., Oudega, M., and Bunge, M. B. (2003). Delayed transplantation of olfactory ensheathing glia promotes sparing/regeneration of supraspinal axons in the contused adult rat spinal cord. J. Neurotrauma 20, 1-16. doi: $10.1089 / 08977150360517146$

Privat, A., Mansour, H., Rajaofetra, N., and Geffard, M. (1989). Intraspinal transplants of serotonergic neurons in the adult rat. Brain Res. Bull. 22, 123-129. doi: 10.1016/0361-9230(89)90136-6

Rajaofetra, N., Passagia, J. G., Marlier, L., Poulat, P., Pellas, F., Sandillon, F., et al. (1992a). Serotoninergic, noradrenergic and peptidergic innervation of Onuf's nucleus of normal and transected spinal cords of baboons (Papiopapio). J. Comp. Neurol. 318, 1-17. doi: 10.1002/cne.9031 80102

Rajaofetra, N., Poulat, P., Marlier, L., Proust, F., Drian, M. J., Passagia, J. G., et al. (1989a). First transplantation of embryonic serotonergic neurons in primate spinal cord. C. R. Acad. Sci. III 310, 81-88.

Rajaofetra, N., Poulat, P., Marlier, L., Sandillon, F., Drian, M. J., König, N., et al. (1992b). Transplantation of embryonic serotonin immunoreactive neurons into the transected spinal cord of adult monkey (Macacafascicularis). Brain Res. 572, 329-334. doi: 10.1016/0006-8993(92)90495-u

Rajaofetra, N., Sandillon, F., Geffard, M., and Privat, A. (1989b). Pre- and postnatal ontogeny of serotonergic projections to the rat spinal cord. J. Neurosci. Res. 22, 305-321. doi: 10.1002/jnr.490220311

Ramer, L. M., Au, E., Richter, M. W., Liu, J., Tetzlaff, W., and Roskams, A. J. (2004). Peripheral olfactory ensheathing cells reduce scar and cavity formation and promote regeneration after spinal cord injury. J. Comp. Neurol. 473, 1-15. doi: $10.1002 /$ cne. 20049

Ramón-Cueto, A., Cordero, M. I., Santos-Benito, F. F., and Avila, J. (2000). Functional recovery of paraplegic rats and motor axon regeneration in their spinal cords by olfactory ensheathing glia. Neuron $25,425-435$. doi: 10.1016/s08966273(00)80905-8

Ramón-Cueto, A., Plant, G. W., Avila, J., and Bunge, M. B. (1998). Long-distance axonal regeneration in the transected adult rat spinal cord is promoted by olfactory ensheathing glia transplants. J. Neurosci. 18, 3803-3815.

Raymond, J. R., Mukhin, Y. V., Gelasco, A., Turner, J., Collinsworth, G., Gettys, T. W., et al. (2001). Multiplicity of mechanisms of serotonin receptor signal transduction. Pharmacol. Ther. 92, 179-212. doi: 10.1016/s01637258(01)00169-3

Ren, L. Q., Wienecke, J., Chen, M., Møller, M., Hultborn, H., and Zhang, M. (2013). The time course of serotonin $2 \mathrm{C}$ receptor expression after spinal transection of rats: an immunohistochemical study. Neuroscience 236, 31-46. doi: 10.1016/j. neuroscience.2012.12.063

Renner, U., Zeug, A., Woehler, A., Niebert, M., Dityatev, A., Dityateva, G., et al. (2012). Heterodimerization of serotonin receptors 5-HT1A and 5-HT7 differentially regulates receptor signalling and trafficking. J. Cell Sci. 125, 2486-2499. doi: $10.1242 /$ jcs. 101337

Ribotta, M. G., Provencher, J., Feraboli-Lohnherr, D., Rossignol, S., Privat, A., and Orsal, D. (2000). Activation of locomotion in adult chronic spinal rats is achieved by transplantation of embryonic raphe cells reinnervating a precise lumbar level. J. Neurosci. 20, 5144-5152.

Rossignol, S., Dubuc, R. J., and Gossard, J. P. (2006). Dynamic sensorimotor interactions in locomotion. Physiol. Rev. 86, 89-154. doi: 10.1152/physrev. 00028.2005

Rossignol, S., and Frigon, A. (2011). Recovery of locomotion after spinal cord injury: some facts and mechanisms. Annu. Rev. Neurosci. 34, 413-440. doi: 10. 1146/annurev-neuro-061010-113746

Rossignol, S., Lund, J. P., and Drew, T. (1988). "The role of sensory inputs in regulating patterns of rhythmical movements in higher vertebrates. A comparison between locomotion, respiration and mastication," in Neural Control of Rhythmic Movements in Vertebrates, eds A. H. Cohen, S. Rossignol and S. Grillner (New York: Wiley), 201-283.

Rudnick, G., and Clark, J. (1993). From synapse to vesicle: the reuptake and storage of biogenic amine neurotransmitters. Biochim. Biophys. Acta 1144, 249-263. doi: 10.1016/0005-2728(93)90109-s

Schloss, P., Mayser, W., and Betz, H. (1992). Neurotransmitter transporters. A novel family of integral plasma membrane proteins. FEBS Lett. 307, 76-80. doi: 10. 1016/0014-5793(92)80905-v
Schmidt, B. J., and Jordan, L. M. (2000). The role of serotonin in reflex modulation and locomotor rhythm production in the mammalian spinal cord. Brain Res. Bull. 53, 689-710. doi: 10.1016/s0361-9230(00)00402-0

Scullion, K., Boychuk, J. A., Yamakawa, G. R., Rodych, J. T., Nakanishi, S. T., Seto, A., et al. (2013). Serotonin 1A receptors alter expression of movement representations. J. Neurosci. 13, 4988-4999. doi: 10.1523/jneurosci.4241-12. 2013

Segal, M. (1990a). Serotonin attenuates a slow inhibitory postsynaptic potentialin rat hippocampal neurons. Neuroscience 36, 631-641. doi: 10.1016/03064522(90)90006-p

Segal, M. (1990b). A subset of local interneurons generate slow inhibitory postsynaptic potentials in hippocampal neurons. Brain Res. 511, 163-164. doi: 10. 1016/0006-8993(90)90236-5

Shapkova, E. Y. (2004). "Spinal locomotor capability revealed by electrical stimulation of the lumbar enlargement in paraplegic patients," in Progress in Motor Control Volume Three, eds M. Latash and M. Levin (Champaign, IL: Human Kinetics Publishers), 253-289.

Shapkova, E. Y., and Mushkin, L. A. (2002). Spinal cord stepping electrostimulation as a method for recovery of locomotor activity invertebrogenic myelopathies. Med. Tekh. 6, 29-32.

Shapkova, E. Y., and Schomburg, E. D. (2001). Two types of motor modulation underlying human stepping evoked by spinal cordelectrical stimulation (SCES). Acta Physiol. Pharmacol. Bulg. 26, 155-157.

Shik, M. L., Severin, F. V., and Orlovskiy, G. N. (1966). Control of walking and running by means of electric stimulation of the midbrain. Biofizika 11, 659-666.

Shimada, T., Takai, Y., Shinohara, K., Yamasaki, A., Tominaga-Yoshino, K., Ogura, A., et al. (2012). A simplified method to generate serotonergic neurons from mouse embryonic stem and induced pluripotent stem cells. J. Neurochem. 122, 81-93. doi: 10.1111/j.1471-4159.2012.07724.x

Sholomenko, G. N., and Steeves, J. D. (1987). Effects of selective spinal cord lesions on hind limb locomotion in birds. Exp. Neurol. 95, 403-418. doi: 10.1016/00144886(87)90148-8

Sławińska, U., Miazga, K., Cabaj, A. M., Leszczyńska, A. N., Majczyński, H., Nagy, J. I., et al. (2013). Grafting of fetal brainstem 5-HT neurons into the sublesional spinal cord of paraplegic rats restores coordinated hindlimb locomotion. Exp. Neurol. 247, 572-581. doi: 10.1016/j.expneurol.2013.02.008

Sławińska, U., Miazga, K., and Jordan, L. M. (2014a). 5- $\mathrm{HT}_{2}$ and 5-HT7 receptor agonists facilitate plantar stepping in chronic spinal rats through actions on different populations of spinal neurons. Front. Neural Circuits. 8:95. doi: 10. 3389/fncir.2014.00095

Sławińska, U., Miazga, K., and Jordan, L. M. (2014b). The role of serotonin in the control of locomotor movements and strategies for restoring locomotion after spinal cord injury. Acta Neurobiol. Exp. (Wars) 74, 172-187.

Steeves, J. D., and Jordan, L. M. (1984). Autoradiographic demonstration of the projections from the mesencephaliclocomotor region. Brain Res. 307, 263-276. doi: 10.1016/0006-8993(84)90480-3

Steeves, J. D., Sholomenko, G. N., and Webster, D. M. (1987). Stimulation of the pontomedullary reticular formation initiates locomotion in decerebrate birds. Brain Res. 401, 205-212. doi: 10.1016/0006-8993(87)91406-5

Takakusaki, K., Saitoh, K., Harada, H., and Kashiwayanagi, M. (2004). Role of basal ganglia-brainstem pathways in the control of motor behaviors. Neurosci. Res. 50, 137-151. doi: 10.1016/j.neures.2004.06.015

Takeuchi, Y., Kimura, H., and Sano, Y. (1982). Immunohistochemical demonstration of serotonin neurons in the brainstem of the rat and cat. Cell Tissue Res. 224, 247-267. doi: 10.1007/bf00216872

Tansey, K. E. (2010). Neural plasticity and locomotor recovery after spinal cord injury. $P M R$ 2(Suppl. 2), S220-S226. doi: 10.1016/j.pmrj.2010. 10.007

Tetzlaff, W., Okon, E. B., Karimi-Abdolrezaee, S., Hill, C. E., Sparling, J. S., and Plemel, J. R. (2011). A systematic review of cellular transplantation therapies for spinal cord injury. J. Neurotrauma 28, 1611-1682. doi: 10.1089/neu.2009. 1177

Thompson, C. K., Jayaraman, A., Kinnaird, C., and Hornby, T. G. (2011). Methods to quantify pharmacologically induced alterations in motor function in human incomplete SCI. J. Vis. Exp. 50, 1-7. doi: 10.3791/2148

Tobias, C. A., Shumsky, J. S., Shibata, M., Tuszynski, M. H., Fischer, I., Tessler, A., et al. (2003). Delayed grafting of BDNF and NT-3 producing fibroblasts into the injured spinal cord stimulates sprouting, partially rescues 
axotomized red nucleus neurons from loss and atrophy and provides limited regeneration. Exp. Neurol. 184, 97-113. doi: 10.1016/s0014-4886(03) 00394-7

Torres, G. E., Gainetdinov, R. R., and Caron, M. G. (2003). Plasma membrane monoamine transporters: structure, regulation and function. Nat. Rev. Neurosci. 4, 13-25. doi: 10.1038/nrn1008

Ung, R. V., Landry, E. S., Rouleau, P., Lapointe, N. P., Rouillard, C., and Guertin, P. A. (2008). Role of spinal 5-HT2 receptor subtypes in quipazine-induced hindlimb movements after a low-thoracic spinal cord transection. Eur. J. Neurosci. 28, 2231-2242. doi: 10.1111/j.1460-9568.2008.06508.x

Werry, T. D., Loiacono, R., Sexton, P. M., and Christopoulos, A. (2008). RNA editing of the serotonin 5-HT2C receptor and its effects on cell signalling, pharmacology and brain function. Pharmacol. Ther. 119, 7-23. doi: 10.1016/j. pharmthera.2008.03.012

Wienecke, J., Ren, L. Q., Hultborn, H., Chen, M., Møller, M., Zhang, Y., et al. (2014). Spinal cord injury enables aromatic L-amino acid decarboxylase cells to synthesize monoamines. J. Neurosci. 34, 11984-12000. doi: 10.1523/jneurosci. 3838-13.2014

Zhang, W., and Grillner, S. (2000). The spinal 5-HT system contributes to the generation of fictive locomotion in lamprey. Brain Res. 879, 188-192. doi: 10. 1016/s0006-8993(00)02747-5
Zörner, B., Bachmann, L. C., Filli, L., Kapitza, S., Gullo, M., Bolliger, M., et al. (2014). Chasing central nervous system plasticity: the brainstem's contribution to locomotor recovery in rats with spinal cord injury. Brain 137, 1716-1732. doi: 10.1093/brain/awu078

Conflict of Interest Statement: The authors declare that the research was conducted in the absence of any commercial or financial relationships that could be construed as a potential conflict of interest.

Received: 04 August 2014; accepted: 28 December 2014; published online: 09 February 2015.

Citation: Ghosh $M$ and Pearse DD (2015) The role of the serotonergic system in locomotor recovery after spinal cord injury. Front. Neural Circuits 8:151. doi: 10.3389/fncir.2014.00151

This article was submitted to the journal Frontiers in Neural Circuits.

Copyright $\odot 2015$ Ghosh and Pearse. This is an open-access article distributed under the terms of the Creative Commons Attribution License (CC BY). The use, distribution and reproduction in other forums is permitted, provided the original author(s) or licensor are credited and that the original publication in this journal is cited, in accordance with accepted academic practice. No use, distribution or reproduction is permitted which does not comply with these terms. 